\title{
Chromophoric dissolved organic matter (CDOM) in first-year sea ice in the western Canadian Arctic
}

\author{
Huixiang Xie ${ }^{*}$, Cyril Aubry ${ }^{1}$, Yong Zhang ${ }^{2}$, Guisheng Song ${ }^{3}$ \\ Institut des Sciences de la Mer de Rimouski, Université du Québec à Rimouski, Rimouski, Québec G5L 3A1, Canada
}

\section{A R T I C L E I N F O}

\section{Article history:}

Received 19 March 2014

Received in revised form 13 June 2014

Accepted 16 July 2014

Available online 31 July 2014

\section{Keywords:}

CDOM

Absorption coefficient

MAAs

Photochemistry

Sea ice

Arctic

\begin{abstract}
A B S T R A C T
We monitored the spatiotemporal progression of chromophoric dissolved organic matter (CDOM) in first-year sea ice in the western Canadian Arctic between mid-March and early July 2008. CDOM abundance in bottom ice, as quantified by absorption coefficient at $325 \mathrm{~nm}, a_{\text {СоОм }}(325)$, showed a positive, linear relationship with the concentration of chlorophyll $a$, being low at the start of ice algal accumulation, highly enriched during the peak bloom and early post-bloom, and depleted again during sea ice melting. Vertical profiles of CDOM in early and late spring were typically characterized by slight to moderate elevations at both the surface and bottom and rather constancy within the interior ice. In the ice algae-thriving mid-spring, L-type profiles prevailed due to extremely high CDOM in the lowermost $10-\mathrm{cm}$ layer. Bottom-layer CDOM in landfast ice $\left(a_{\mathrm{CDOM}}(325): 15.8 \mathrm{~m}^{-1}\right)$ more than doubled that in drift ice $\left(a_{\mathrm{CDOM}}(325): 6.6 \mathrm{~m}^{-1}\right)$. CDOM in the ice cover, except the bottom layer, was generally lower than or similar to that in the under-ice surface water. Salinity accounted for 58\% of the CDOM variability in drift ice having minimal terrestrial and ice algal signatures. CDOM absorption spectra of algaerich bottom ice samples exhibited ultraviolet (UV) absorption shoulders attributable to mycosporine-like amino acids (MAAs). These compounds were readily photodegradable by solar UV radiation. Our results suggest that 1 ) inclusion of organic solutes and in situ biological production are the dominant processes controlling the distribution of CDOM in sea ice in the study area, 2) biological production in bottom ice is a minor source of CDOM to the underlying surface water; 3) CDOM plays a critical role in shielding sympagic organisms in bottom ice against UV radiation; 4) the MAAs are effective photoprotectants only under low-UV conditions.
\end{abstract}

(C) 2014 Elsevier B.V. All rights reserved.

\section{Introduction}

Chromophoric dissolved organic matter (CDOM) plays vital roles in marine physics, optics, ecosystem functioning, and biogeochemical cycles. Physically, CDOM is a useful tracer of water-mass circulations (Nelson et al., 2010; Xie et al., 2012; Matsuoka et al., 2012) and directly contributes to the heating budget of surface oceans by absorbing solar radiation over the ultraviolet (UV) and visible wavelengths (Hill, 2008). Optically, the absorption of sunlight by CDOM, usually decreasing exponentially with wavelength, strongly modifies the intensity and spectral composition of solar radiation in the water column (Kirk, 1980). Ecologically, the strong short wave-absorbing character of CDOM mitigates the deleterious effects of solar UV-B $(280-320 \mathrm{~nm})$

\footnotetext{
* Corresponding author. Tel.: +1 418723 1986x1767; fax: +1 4187241842.

E-mail address: huixiang_xie@uqar.ca (H.Xie).

1 Present address: Département de biologie, Université Laval, Québec, Québec G1V 0A6, Canada.

2 Present address: Key Laboratory of Coastal Zone Environmental Processes and Ecological Remediation, Yantai Institute of Coastal Zone Research, Chinese Academy of Sciences, Yantai, Shandong Province 264003, PR China.

3 Present address: School of Marine Science and Engineering, Tianjin University of Science and Technology, Tianjin 300457, PR China.
}

radiation on marine organisms while CDOM absorption in the visible can reduce light availability for primary producers in colored waters (Zepp, 2003) and compromise remote sensing-based assessment of marine primary productivity (Antoine et al., 1996). Geochemically, CDOM is an important fraction of the dissolved organic matter (DOM) pool, which is generally resistant to metabolic attack but susceptible to photodegradation, the latter profoundly impacting the cycling of carbon, sulfur, nitrogen, trace metals, and trace gases in the surface ocean (Zafiriou, 2002; Zepp, 2003).

On a volume basis, the Arctic Ocean receives a disproportionally high fluvial discharge which could be further augmented due to climate warming (Peterson et al., 2002). The organic-laden freshwater runoff renders the Arctic surface water to be enriched with DOM and CDOM relative to other major ocean basins (Opsahl et al., 1999). The last decade has seen significant progresses in understanding the distributions, sources, sinks, and transformations of CDOM in Arctic seawater (Pegau, 2002; Guéguen et al., 2007; Stedmon et al., 2011a; Granskog et al., 2012) and in the application of CDOM as a tool for water-mass identification in this complex circulation system (Matsuoka et al., 2012). In contrast, studies on CDOM in Arctic sea ice, and in polar sea ice in general, are sporadic and rudimentary despite the fact that sea ice plays a paramount role in polar ocean's ecosystems (Gosselin et al., 1997; Thomas 
and Papadimitriou, 2003; Mundy et al., 2009; Barber et al., 2012). Biooptical analysis of several ice cores taken from the Baffin Bay suggests that CDOM substantially contributes to the attenuation of solar radiation within the ice (Belzile et al., 2000) and that sea ice may be an important source of CDOM in the surface water of the North Water polynya (Scully and Miller, 2000). Xie and Gosselin (2005) reported high enrichment of CDOM in the bottom layer of sea ice in the Franklin Bay, western Canadian Arctic during the ice algae bloom season and suggested the presence of significant CDOM-driven photoreactions based on the observation of carbon monoxide photoproduction from CDOM within sea ice. In a modeling study on the contribution of CDOM to the heating budget of Arctic seawater, Hill (2008) proposed that ice algae-derived CDOM is the dominant component of the CDOM pool resulting in the increased solar energy trapped in the mixed layer of the Chukchi Sea. Studies in the strongly fluvially impacted subarctic Gulf of Finland have demonstrated the importance of CDOM as a solar UV absorber within the sea ice (Ehn et al., 2004; Uusikivi et al., 2010), the influence of riverine input on the source composition of sea ice CDOM (Granskog et al., 2006), and the distinct optical properties of CDOM in sea ice as compared to that in under-ice seawater (Ehn et al., 2004; Granskog et al., 2005). More recently, surveys have been made on the distribution, photoreactivity (Norman et al., 2011), and fluorescent characteristics (Stedmon et al., 2011b) of DOM and CDOM in Antarctic sea ice in the Weddell Sea and the South Indian Ocean off Wiles Land. The CDOM in Antarctic sea ice contains mycosporine-like amino acids (MAAs) (Norman et al., 2011) and amino-acid-like fluorescent materials that are unique to sea ice brine (Stedmon et al., 2011b).

Here we report to date the largest dataset of CDOM in Canadian Arctic sea ice. Our objectives are to characterize the temporal and spatial variations of CDOM in first-year sea ice in relation to relevant physical, biological, and chemical variables; to assess the significance of sea ice as a source of CDOM to ambient seawater; and to quantitatively assess the photoreactivity of MAAs produced by ice algae. This study provides useful information for sea ice bio-optical modeling and for better understanding the origin and cycling of CDOM in sea ice and the underlying water column.

\section{Methods}

\subsection{Sea ice sampling and analysis}

Ice sampling was conducted in the western Canadian Arctic from 17 March to 6 July 2008 during the 2007-2008 International Polar YearCircumpolar Flaw Lead (IPY-CFL) system study aboard the CCGS Amundsen (Barber et al., 2010). Sampling was focused on first-year sea ice, including both landfast and drift ice. Drift ice stations were exclusively located in the northwest Amundsen Gulf while landfast ice stations were distributed in several areas encompassing the Franklin and Darnley Bays, the Prince of Wales and M'Clure Straits, and the west Banks Island shelf (Fig. 1). At drift ice stations, the ship followed the same ice floe until sampling was completed and then re-positioned to the next ice floe. Most stations were visited only once but some were sampled 2-4 times, often 3 days apart. The stations visited more than once were D33 (25/03, 28/03, 31/03), D36 (06/04, 09/04), D43 (26/04, 29/04, 02/05, 05/05), F1 (08/05, 09/05), F2 (13/05, 16/05), and F7 (09/06, 12/06, 18/06), the numbers in parentheses being sampling day/month. Although these short-term fixed stations could serve to capture temporal variability in certain periods of time, overall our sampling protocol integrated both temporal and spatial variabilities due to the change of sampling locations.

Sites with moderate to low snow depths (typically $<5 \mathrm{~cm}$ ) were selected for ice extraction. Several ice cores were taken at each station using a MARK II coring system ( $9 \mathrm{~cm}$ in diameter, Kovacs Enterprises). One of the extracted ice cores was cut into 7-9 10-cm thick sections with a stainless steel surgical saw and the central portion of each section was taken out using an electric drill fitted with a cylindrical,

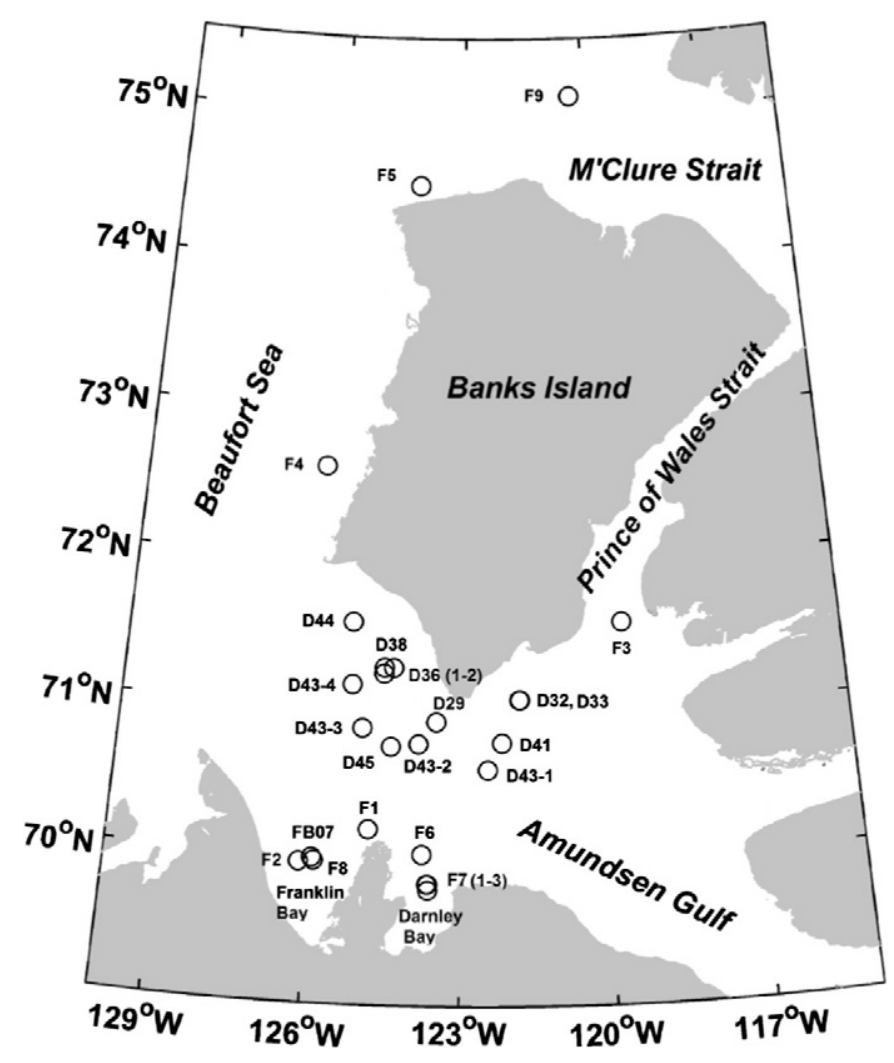

Fig. 1. Map of sampling stations. D stands for drift ice and F for landfast ice. Stations sampled at multiple times are indicated by numbers in parentheses or followed by hyphens.

saw-toothed steel bit having dimensions of $4 \mathrm{~cm}$ in diameter and $10 \mathrm{~cm}$ in length (Song et al., 2011; Randall et al., 2012). The extracted central portion was immediately transferred into a pre-cleaned $200-\mathrm{mL}$ all-glass syringe (Perfektum $\left.{ }^{\circledR}\right)$ capped with a nylon valve. Direct sunlight was avoided during sample manipulation. The syringes, placed in a plastic cooler, were immediately brought to the ship and then immersed in a bucket of tap water to thaw the ice. The meltwater was gently passed through a $0.2-\mu \mathrm{m}$ polyethersulfone membrane syringe filter (Whatman) and collected into acid-cleaned 60-mL glass bottles with PTFE-lined screw caps (Qorpak). The samples were transported under refrigeration and darkness to a land-based laboratory at Rimouski for analysis.

Samples were allowed to warm up to room temperature before CDOM optical density measurements. The spectral optical density of CDOM in bulk ice, $\mathrm{OD}_{\mathrm{CDOMi}}(\lambda)$, was scanned from 800 to $200 \mathrm{~nm}$ at 1-nm intervals using a Perkin-Elmer Lambda 35 dual beam spectrophotometer fitted with a $10-\mathrm{cm}$ rectangular quartz cell and referenced to Nanopure water. For highly colored samples, a 1-cm quartz cuvette was used to keep the measured absorbance within the linear range of the Beer-Lambert law. The cell was rinsed with methanol, pure water, and sample water between individual scans. A baseline correction was made by subtracting the optical density averaged over $683-687 \mathrm{~nm}$ from all $\mathrm{OD}_{\mathrm{CDOMi}}$ values at $\lambda<683 \mathrm{~nm}$ (Babin et al., 2003). The measured $\operatorname{OD}_{\mathrm{CDOMi}}(\lambda)$ was converted to the absorption coefficient of CDOM in bulk ice, $a_{\mathrm{CDOMi}}(\lambda)\left(\mathrm{m}^{-1}\right)$, with the following equation:

$a_{\mathrm{CDOMi}}(\lambda)=2.303 \times \mathrm{OD}_{\mathrm{CDOMi}}(\lambda) / L$

where $L(\mathrm{~m})$ is the light pathlength of the cell. The lower detection limit of $a_{\mathrm{CDOMi}}$ with the $10-\mathrm{cm}$ cell, defined as three times the standard deviation of five replicate analyses of pure water, was $0.02 \pm 0.01 \mathrm{~m}^{-1}$ from $250 \mathrm{~nm}$ to $700 \mathrm{~nm}$. The CDOM samples were also analyzed for salinity and concentrations of dissolved organic carbon (DOC). Separate ice 
cores were used for the determination of chlorophyll $a$ concentration ([chl-a]) and ice temperature. Readers are referred to a companion paper by Song et al. (2011) for the methods and results of these measurements.

During ice sampling, the metal ice-coring bit was corroded by seaice brine. The corrosion was suspected to be responsible for the occurrence of a bulge in the absorption spectra of some samples that consistently fell in the wavelength range from $~ 340$ to $\sim 400 \mathrm{~nm}$ and peaked at $\sim 370 \mathrm{~nm}$ (Fig. 2). To confirm this suspicion, the rusted bit was thoroughly rinsed with Nanopure water (to remove residual sea ice and its constituents), air-dried, and rinsed again with pure water. Water from the final rinsing was collected and analyzed for absorbance and DOC. The obtained absorption spectrum showed an elevation with its spectral range and peak-absorption wavelength identical to those of the protrusion in the samples' spectra. The concentration of DOC was negligible, suggesting that the absorbance contamination stemmed from inorganics, likely corrosion-formed metal oxides. Ice subsampling at station D43 with a stainless-steel surgical saw eliminated the absorption bulge, further confirming that the contamination stemmed from the metal bit. A correction on this artifact was made by an exponential fit of the measured absorption coefficients to wavelength over two narrow spectral windows, each adjacent to the lower and upper bounds of the absorption bulge, respectively (Fig. 2). To further minimize biases, we report absorption coefficients at $325 \mathrm{~nm}\left(a_{\mathrm{CDOMi}}(325)\right)$, a wavelength that is outside the artifact's spectral range. Although this wavelength is within the spectral ranges of absorption shoulders present in a limited number of samples (see Section 3.5), tests with other wavelengths (e.g. $412 \mathrm{~nm}$ ) indicate that the choice of $325 \mathrm{~nm}$ does not affect the results and conclusions reported here, since the absorption shoulders are relatively gentle.

\subsection{Laboratory irradiation}

During the 2004 Canadian Arctic Shelf Exchange Study (CASES) (Fortier and Cochran, 2008), filtered meltwater of ice algae-laden bottom sea ice collected in mid-May from a site $\left(70.046^{\circ} \mathrm{N}, 126.301^{\circ} \mathrm{W}\right)$ in the Franklin Bay (Fig. 1) showed an absorbance peak characteristic of MAAs; the peak can be readily photobleached ( $\mathrm{H}$. Xie, unpublished data). To re-confirm this observation, a bunch of lowermost 35-cm ice sections were collected from station F2 on 16 May 2008 using the stainless-steel surgical saw and thawed at $4{ }^{\circ} \mathrm{C}$. Meltwater from different ice sections was combined together and gravity-filtered using a sterile Pall AcroPak 500 capsule sequentially containing $0.8-\mu \mathrm{m}$ and $0.2-\mu \mathrm{m}$ polyethersulfone membrane filters. The filtrate was brought to Rimouksi under cool and dark conditions and then irradiated with an

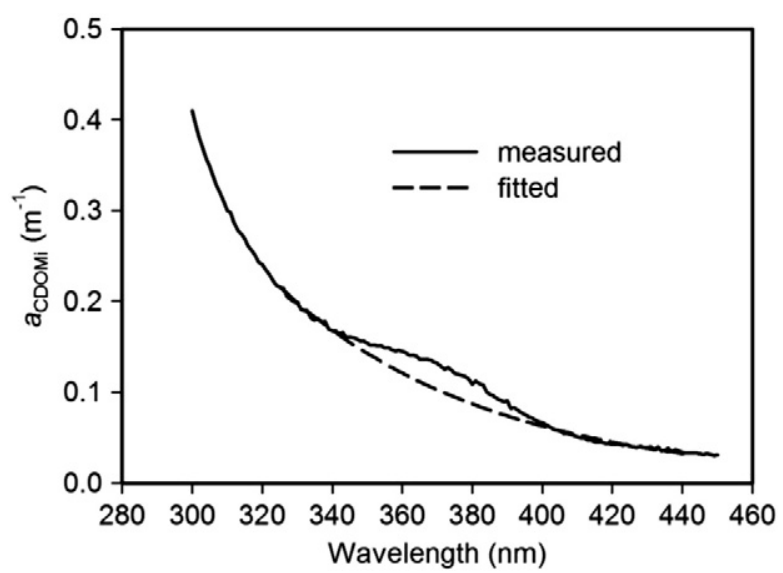

Fig. 2. Example of an absorption shoulder over 340-400 nm resulting from contamination by corrosion of the metal sampling bit. Dashed line represents the correction on the contamination using data from an exponential fit of measured absorption coefficient values to wavelength over 320-330 nm and 420-435 nm combined. illumination system described previously (Zhang et al., 2006; Xie et al., 2009). Briefly, the filtrate was transferred into 10 quartzwindowed cylindrical cells (volume: $104 \mathrm{~mL}$; i.d.: $3.4 \mathrm{~cm}$ ) which were then kept at constant temperature $\left(2 \pm 1{ }^{\circ} \mathrm{C}\right)$ and irradiated using a SUNTEST CPS solar simulator equipped with a $1.5-\mathrm{kW}$ xenon lamp. Eight successive, subtractive long band-pass optical filters (Schott), each placed over a parallel irradiation cell, created eight spectral treatments. The Schott codes of the filters were WG280, WG295, WG305, WG320, WG345, GG395, GG435, and GG495, the numbers denoting the nominal $50 \%$ transmittance cutoff wavelengths $\left(\lambda_{50 \% \mathrm{r}}\right)$. The external sidewalls of the quartz cells were darkened with electric tape to eliminate lateral light interference between the cells. Spectral irradiance under each filter was measured using an OL-754 spectroradiometer fitted with a 2-inch OL IS-270 integrating sphere calibrated with an OL $752-10 \mathrm{E}$ irradiance standard. Irradiation lasted for $30 \mathrm{~min}$. The remaining two quartz cells served as dark controls. The sampling and irradiation procedures for the CASES sample mentioned above were identical except that the ice sections obtained were thinner $(20 \mathrm{~cm})$ and the irradiation time was shorter (15 min).

\section{Results}

\subsection{General meteorological and hydrological properties}

Detailed information on meteorology and hydrology can be found in the study of Song et al. (2011), their Figs. 1 and 2. In brief, snow depth and ice thickness at sampling stations ranged from 0 to $10 \mathrm{~cm}$ (mean: $4 \mathrm{~cm}$ ) and from 72 to $185 \mathrm{~cm}$ (mean: $134 \mathrm{~cm}$ ), respectively. Dailyaveraged shortwave radiation (285-2800 $\mathrm{nm}$ ) and air temperature increased, albeit with fluctuations, over the sampling course from 160 $\mathrm{W} \mathrm{m}{ }^{-2}$ to $-25{ }^{\circ} \mathrm{C}$ on 17 March to $330 \mathrm{~W} \mathrm{~m}^{-2}$ to $7{ }^{\circ} \mathrm{C}$ on 6 July. Air temperature stayed mostly above $0{ }^{\circ} \mathrm{C}$ from 13 May onward, resulting in snow and sea ice melting. Over the same period of time (17 March to 6 July), sea ice temperature augmented, again with fluctuations, from -21.6 to $-0.8{ }^{\circ} \mathrm{C}$ in the top $10 \mathrm{~cm}$ and from -3.4 to $-0.6{ }^{\circ} \mathrm{C}$ in the bottom $10 \mathrm{~cm}$. The mean bulk ice salinity (ice salinity herein) in the top layer stood at $7.8( \pm 1.5)$ prior to 13 May, decreased to $1.6( \pm 2.2)$ after 13 May, and further dropped to $0.2( \pm 0.2)$ after 2 June; the ice salinity in the bottom layer averaged $6.0( \pm 1.8), 2.8( \pm 1.7)$, and 1.7 $( \pm 1.1)$ for the respective time intervals. The lower salinities observed during the later stages were due apparently to heavier losses of brine caused by warmer temperatures and stronger ice melting. Vertical profiles of ice temperature were typical for first-year sea ice in spring. Temperature generally increased with depth in early spring and profiles switched to a C-shaped structure after ice started melting.

\subsection{CDOM in bottom sea ice}

Following the practice of Song et al. (2011), the bottom-ice data was divided into four groups with respect to [chl- $a$ ] in the lowermost $10-\mathrm{cm}$ layer: low [chl-a] phase 1 (LCP1, 17-31 March), high [chl-a] phase 1 (HCP1, 6 April-5 May), high [chl-a] phase 2 (HCP2, 8-16 May), and low [chl-a] phase 2 (LCP2, 20 May-6 July) (Fig. 3). LCP1 was sampled exclusively on drift ice and corresponded to the early stage of ice algal accumulation. HCP1 and HCP2 covered the peak bloom in drift sea ice and the peak to early post-bloom in landfast sea ice, respectively (Brown et al., 2010). LCP2 was mainly sampled on landfast sea ice (except stations D44 and D45, 30-31 May) and matched the period of sea ice melt. The mean [chl- $a$ ] ( \pm s.d.) for LCP1, HCP1, HCP2, and LCP2 was $54 \pm 43 \mathrm{mg} \mathrm{m}^{-3}, 310 \pm 144 \mathrm{mg} \mathrm{m}^{-3}, 1230 \pm 360 \mathrm{mg} \mathrm{m}^{-3}$, and $14.0 \mathrm{mg} \mathrm{m}^{-3}$, respectively. The bottom layer of landfast ice thus contained about four times more chl- $a$ than did the drift ice over the high algal biomass periods.

CDOM abundance in bottom ice, as indicated by $a_{\mathrm{CDOMi}}(325)$, roughly co-varied with [chl-a] (Fig. 3 ), with the mean $a_{\mathrm{CDOMi}}(325)$ for HCP1 $\left(6.56 \mathrm{~m}^{-1}\right)$ being ca. tenfold that of LCP1 $\left(0.60 \mathrm{~m}^{-1}\right)$ and the 


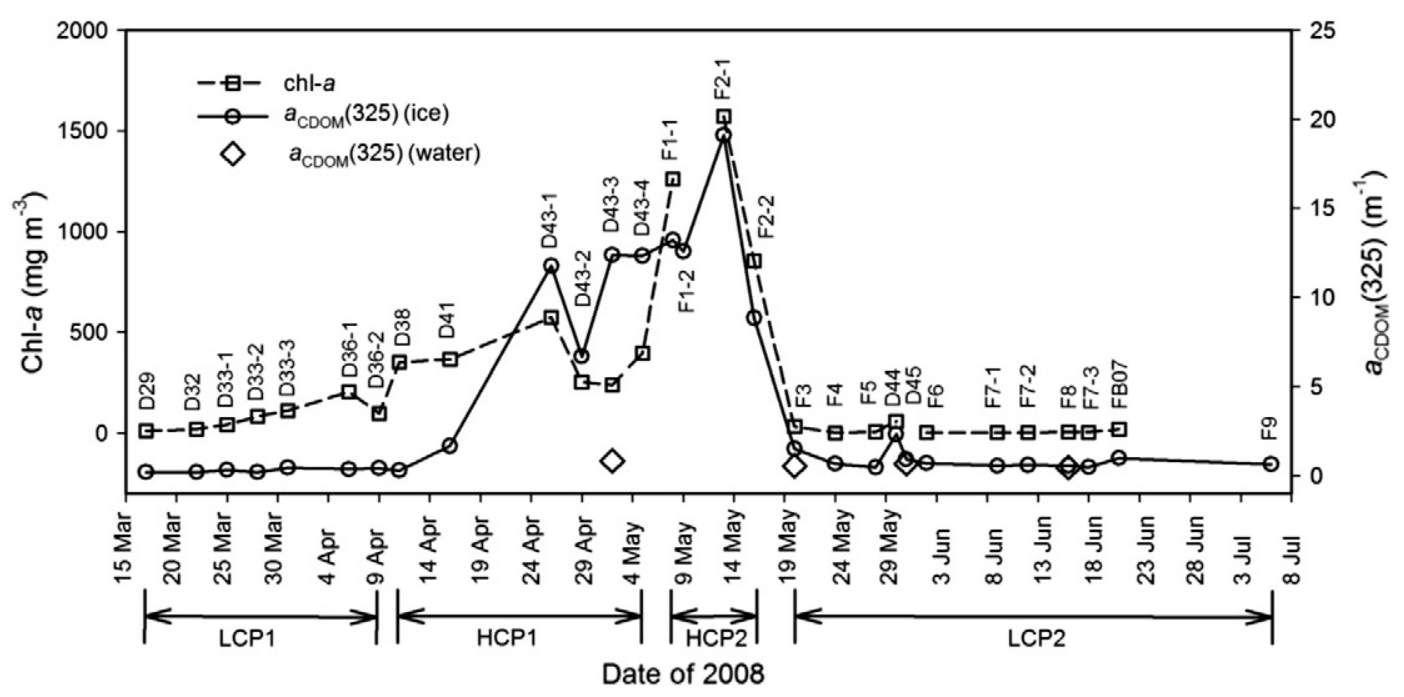

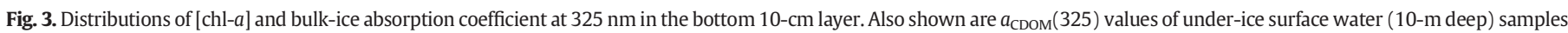
collected at four ice stations. LCP1 = low [chl- $a$ ] phase one; HCP1 = high [chl- $a$ ] phase one; HCP2 = high $[$ chl- $a$ ] phase two; LCP2 = low [chl- $a$ ] phase two.

mean $a_{\mathrm{CDOMi}}(325)$ for HCP2 $\left(15.84 \mathrm{~m}^{-1}\right)$ being ca. 22 times that of LCP2 $\left(0.71 \mathrm{~m}^{-1}\right)$. During the bloom periods, CDOM in landfast ice (i.e. HCP2) was on average 2.4 times more abundant than in drift ice (i.e. HCP1). Temporal variations in $a_{\mathrm{CDOMi}}(325)$ at the short-term fixed stations were generally small but conspicuous peaks and troughs did occur episodically (e.g. stations D33 and D42, Fig. 3), as was true for [chl-a] as well. These fluctuations are consistent with the notion that biogeochemical properties in sea ice are often patchy even on fine spatial scales (Lizotte, 2003). The $a_{\mathrm{CDOMi}}(325)$ showed a strong correlation to [chl-a] for landfast ice while the relationship for drift ice was only marginally significant (Fig. 4). The poorer correlation for drift ice was due partly to a lag of the progression of $a_{\mathrm{CDOMi}}(325)$ behind that of [chl-a] during the early spring: while $a_{\mathrm{CDOMi}}(325)$ remained rather stable (range: 0.20-0.46 $\mathrm{m}^{-1}$ ) from 17 March to April 11, [chl-a] increased by a factor of 29 from $12.1 \mathrm{mg} \mathrm{m}^{-3}$ to $350 \mathrm{mg} \mathrm{m}^{-3}$ (Fig. 3). Sea-ice $a_{\mathrm{CDOMi}}(325)$ was far above the absorption coefficient at $325 \mathrm{~nm}$ for under-ice surface water $\left(a_{\mathrm{CDOMw}}(325)\right)$ during the high chl- $a$ phases, whereas the two quantities were typically comparable during LCP2 (Fig. 3). Note that sympagic organisms were subjected to osmotic stress during the thawing of ice samples, which could potentially induce loss of intracellular DOM and thus bias the CDOM absorption coefficients toward

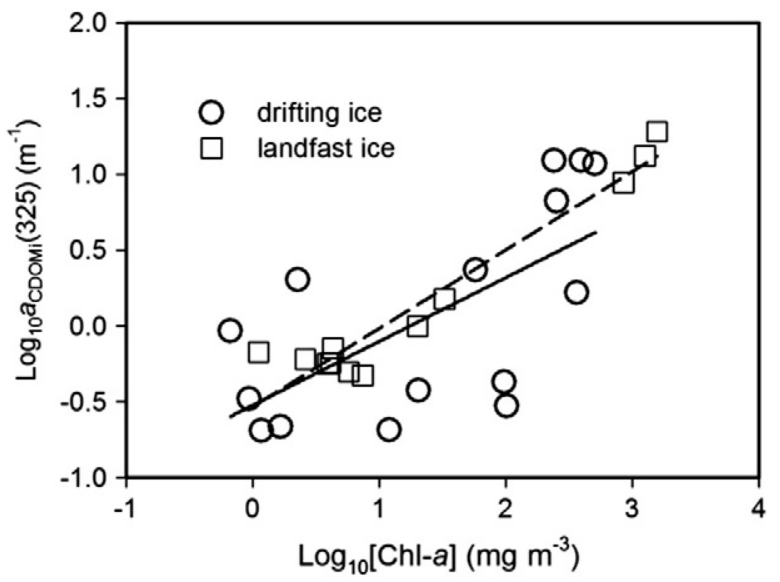

Fig. 4. Scatter plots of $a_{\mathrm{CDOMi}}$ (325) against [chl-a] for the bottom 10-cm ice layer. Solid and dashed lines are best fits to the data of drift and landfast ice, respectively. Fitted equations are $\mathrm{Y}=0.42 * \mathrm{X}-0.52\left(\mathrm{R}^{2}=0.433, \mathrm{~N}=15\right)$ for drift ice and $\mathrm{Y}=0.52 * \mathrm{X}-0.53$ $\left(\mathrm{R}^{2}=0.932, \mathrm{~N}=12\right)$ for landfast ice. Because of the large dynamic ranges of $a_{\mathrm{CDOMi}}(325)$ and $[\mathrm{chl}-a]$ encountered, both the $\mathrm{x}$ - and $\mathrm{y}$-axes are plotted on logarithmic scales to minimize biases of the regressions toward large values. higher values, particularly when the algal biomass was high. However, this loss has been considered to be small relative to the extracellular DOM pool (Thomas et al., 1998, 2001). The decoupling between CDOM and [chl-a] (and between DOC and [chl-a], Song et al., 2011) over the early spring suggests that the effect of the osmotic stress, if any, was low in the present study. This decoupling also presents a line of evidence that release of DOM due to cell breakage associated with the syringe filtration was minor as well.

\subsection{Vertical distribution of $C D O M$}

In total $29 \mathrm{CDOM}$ vertical profiles were collected. Although individual profiles somewhat differed from one to another, they shared basic features within each of the [chl-a]-based groups defined above. We thus report average profiles for each [chl-a] group to capture the dominant characters of the CDOM vertical distribution along with those of salinity and [chl-a].

Salinity profiles were generally C-shaped before ice melting in both drift and landfast ice (Fig. 5A-B and Fig. 6A) but transformed to an inverted C-shape after ice started thawing (Fig. 5C and Fig. 6B). They conform to a typical evolution of salinity structures in first-year sea ice (Eicken, 2003). [Chl-a] profiles were approximately L-shaped throughout the sampling period; the chl- $a$ enrichment in the bottom, however, was far stronger during the high [chl- $a$ ] phases (Fig. 5E and Fig. 6C) than during the low [chl-a] phases (Fig. 5D-F and Fig. 6D), especially for landfast ice. Surface [chl-a] approached zero (mean: $0.16 \mathrm{mg} \mathrm{m}^{-3}$ ) in drift ice for all three [chl-a] phases (Fig. 5D-F) while small but significant amounts of chl- $a$ were found in the top layer of landfast ice, particularly during LCP2 (mean: $1.34 \mathrm{mg} \mathrm{m}^{-3}$ ) (Fig. 6D). LCP1 on drift ice saw a relatively homogenous vertical distribution of CDOM with slight elevations at the surface and bottom (Fig. 5G). The two high [chl-a] phases both displayed L-shaped CDOM profiles with an extraordinary enrichment of CDOM in the bottom (Fig. 5H and Fig. 6E), mimicking the [chl-a] profiles. During the melting season (LCP2), CDOM was quite uniform within the interior but somewhat enhanced in the top and bottom layers (Fig. 5I and Fig. 6F). Under-ice surface water was depleted in CDOM relative to the bottom ice but held similar or higher levels of $\mathrm{CDOM}$ as compared with the interior and surface sea ice (Figs. 5H-I and Fig. 6F).

\subsection{CDOM in brine}

Brine salinity was calculated according to the equation of Eicken (2003): $S_{b}=(1-54.11 / T)^{-1} \times 1000$, where $\mathrm{T}$ is sea ice temperature 

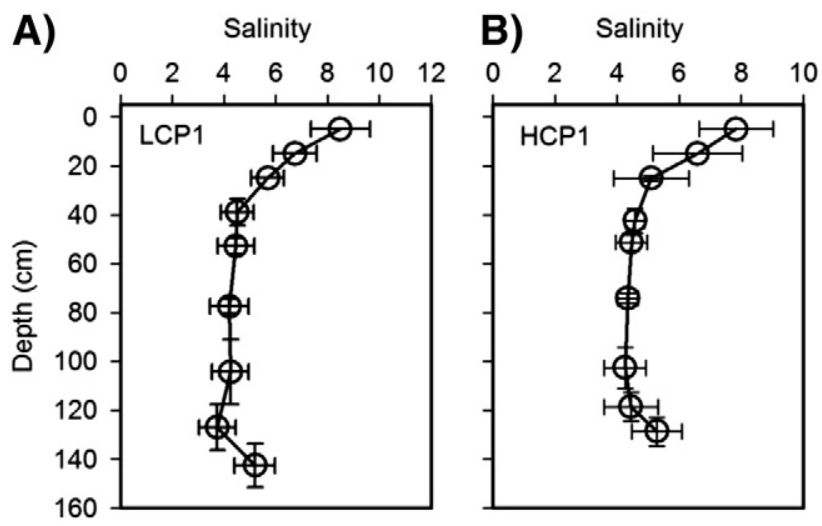

C) Salinity
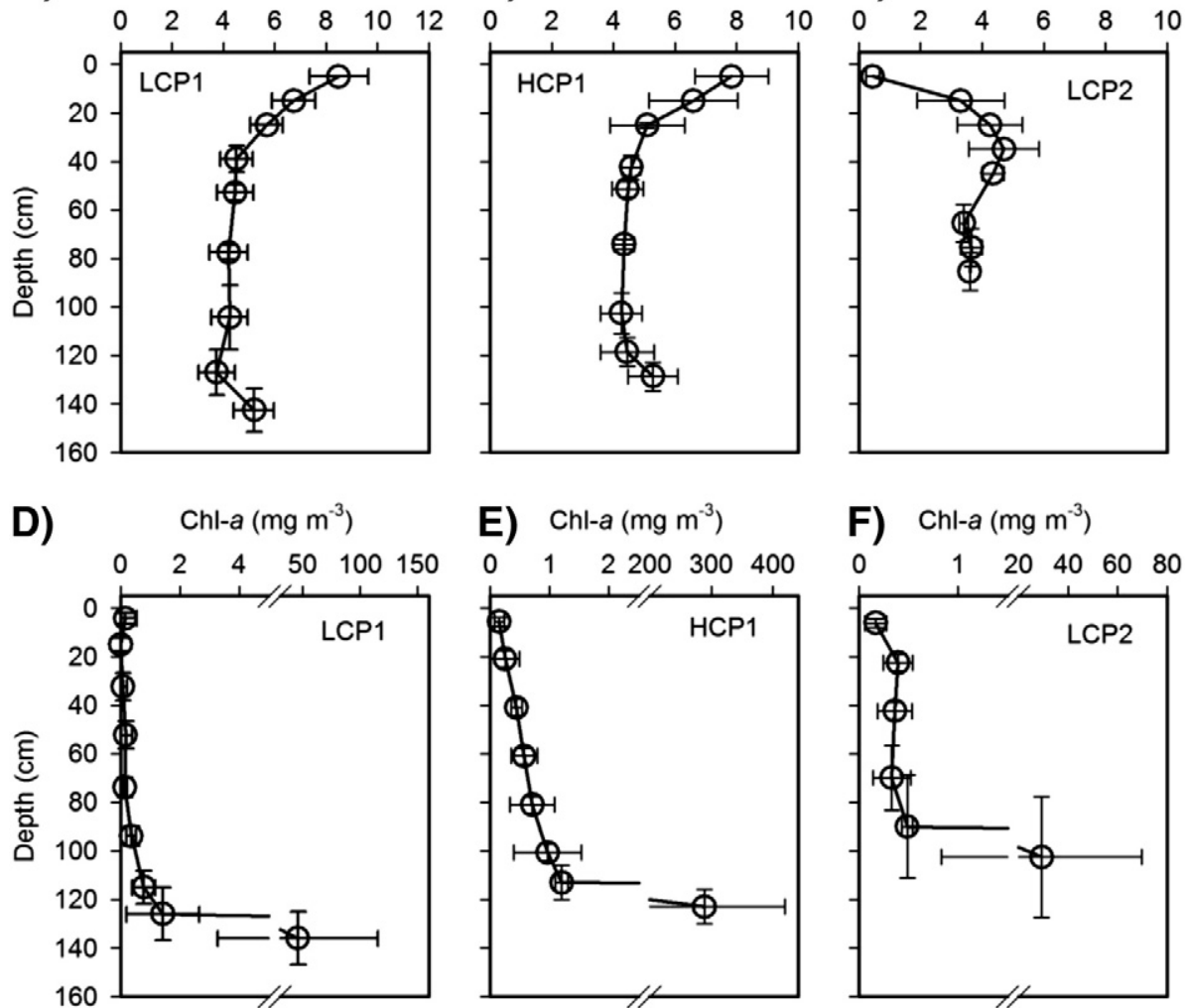

E) $\mathrm{Chl}-\mathrm{a}\left(\mathrm{mg} \mathrm{m}^{-3}\right)$

F) $\mathrm{Chl}-\mathrm{a}\left(\mathrm{mg} \mathrm{m}^{-3}\right)$
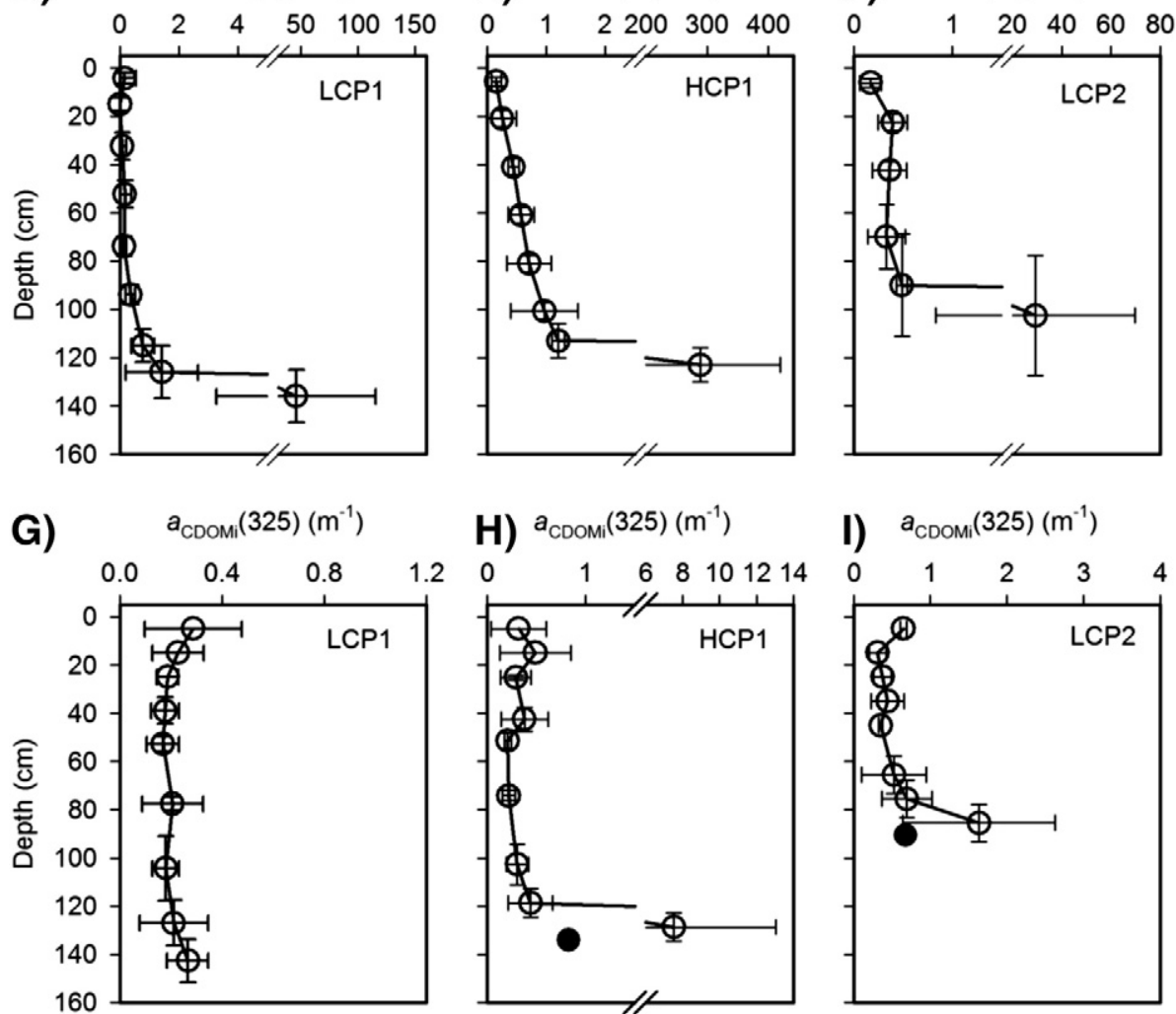

H) $a_{\mathrm{CDOMi}}(325)\left(\mathrm{m}^{-1}\right)$

I) $a_{\text {CDOMi }}(325)\left(m^{-1}\right)$
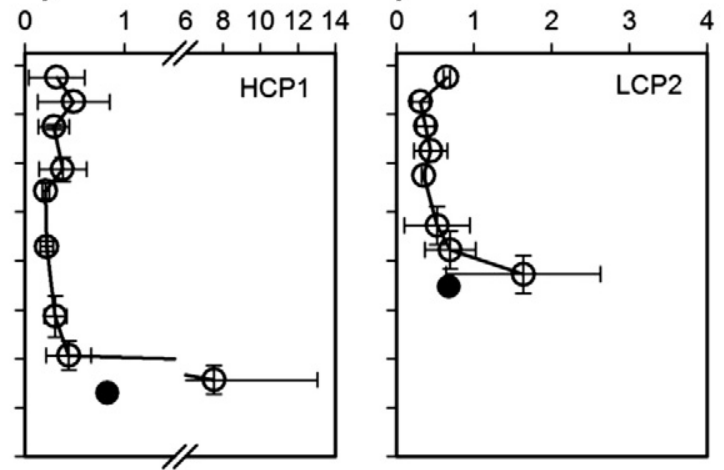

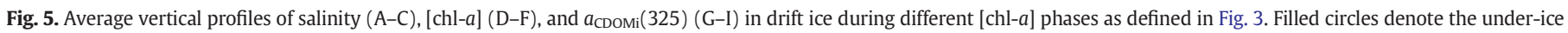
surface water $a_{\mathrm{CDOM}}(325)$ at station D43 (2 May 2008, panel H) and station D45 (panel I). Error bars are one standard deviation.

$\left({ }^{\circ} \mathrm{C}\right)$. Assuming that essentially all CDOM resided in brine, we estimated the spectral absorption coefficient of CDOM for brine, $a_{\mathrm{CDOMb}}(\lambda)$, as $\left(\mathrm{S}_{\mathrm{b}} / \mathrm{S}_{\mathrm{i}}\right) \times a_{\mathrm{CDOMi}}(\lambda)$, where $\mathrm{S}_{\mathrm{i}}$ is salinity of bulk ice. Table 1 compares the statistics of $a_{\mathrm{CDOMi}}(325)$ and $a_{\mathrm{CDOMb}}(325)$. To facilitate discussion, the ice cover was divided into three layers: the top $10 \mathrm{~cm}$, the interior, and the lowermost $10 \mathrm{~cm}$. In the top layer, the mean $a_{\mathrm{CDOMi}}(325)$ changed little between LCP1 $\left(0.29 \mathrm{~m}^{-1}\right)$ and HCP1 $\left(0.32 \mathrm{~m}^{-1}\right)$ for drift ice and between HCP2 $\left(0.44 \mathrm{~m}^{-1}\right)$ and LCP2 $\left(0.47 \mathrm{~m}^{-1}\right)$ for landfast ice; $a_{\mathrm{CDOMi}}(325)$ for landfast ice was $~ 50 \%$ higher than for drift ice. The mean $a_{\mathrm{CDOMb}}(325)$, in descending order, was LCP1 $\left(8.67 \mathrm{~m}^{-1}\right)>\operatorname{HCP} 1\left(5.44 \mathrm{~m}^{-1}\right)>\operatorname{HCP} 2\left(4.91 \mathrm{~m}^{-1}\right)>\operatorname{LCP} 2\left(4.03 \mathrm{~m}^{-1}\right)$; CDOM in brine was, respectively, enriched by $30,17,11$, and 9 times relative to CDOM in bulk sea ice. In the interior sea ice, the mean values of both $a_{\mathrm{CDOMi}}(325)$ and $a_{\mathrm{CDOMb}}(325)$ only slightly differed (range: 2-27\%; mean: $9 \%$ ) from those in the top layer. In the bottom layer, the mean $a_{\mathrm{CDOMb}}(325) / a_{\mathrm{CDOMi}}(325)$ ratio was $5,7,4$, and 13 for the four chronological [chl-a] phases, respectively; the mean
$a_{\mathrm{CDOMb}}(325)$ reached enormous levels of $47.0 \mathrm{~m}^{-1}$ during HCP1 and $65.5 \mathrm{~m}^{-1}$ during HCP2. The mean $a_{\mathrm{CDOMi}}(325)$ values in the bottom layer for HCP1 $\left(6.56 \mathrm{~m}^{-1}\right)$ and HCP2 $\left(15.84 \mathrm{~m}^{-1}\right)$ were, respectively, 19- and 35 -folds those $\left(0.34 \mathrm{~m}^{-1}\right.$ and $\left.0.45 \mathrm{~m}^{-1}\right)$ in the interior while the corresponding enrichment factors for $a_{\mathrm{CDOMb}}(325)$ were 8 and 14. During the two low [chl-a] phases, the mean $a_{\text {CDOMi }}$ (325) values in the bottom layer were 3 (LCP1) and 1.5 (LCP2) times those in the interior. The mean $a_{\mathrm{CDOMb}}(325)$ in the bottom layer was also enriched during LCP2 (9.04 $\mathrm{m}^{-1}$ vs. $\left.4.27 \mathrm{~m}^{-1}\right)$ but depleted during LCP1 $\left(3.27 \mathrm{~m}^{-1}\right.$ vs. $\left.7.50 \mathrm{~m}^{-1}\right)$ as compared to the interior.

\subsection{CDOM absorption spectra and photobleaching of MAAs}

CDOM absorption spectra of bottom ice samples collected during the low [chl-a] phases exhibited a shoulder centered at $\sim 275 \mathrm{~nm}$; the absorption coefficient decreased approximately exponentially at wavelengths longer than $300 \mathrm{~nm}$ (Fig. 7A). These absorption spectra 
A)

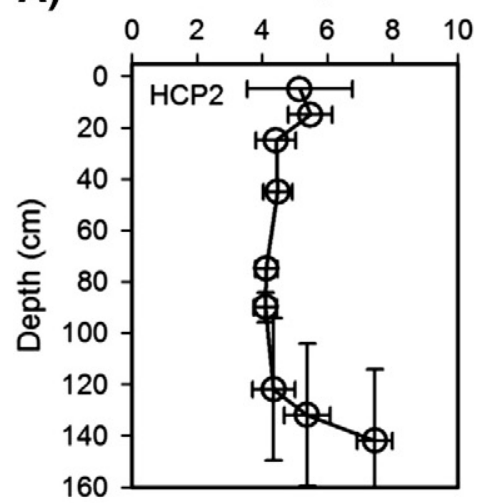

C)

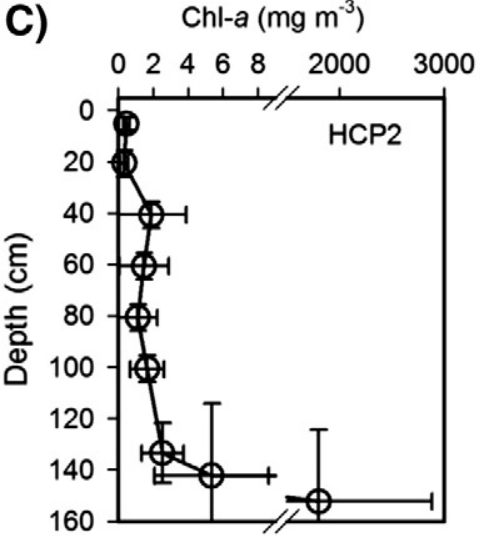

E)
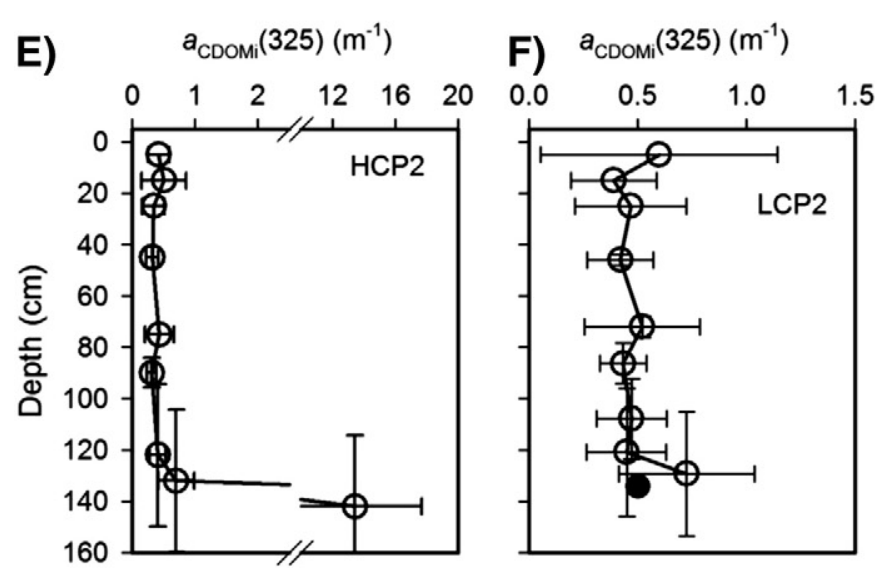

Fig. 6. Average vertical profiles of salinity (A-B), [chl-a] (C-D), and $a_{\mathrm{CDOMi}}(325)$ (E-F) in landfast sea ice over HCP2 and LCP2 as defined in Fig. 3. Filled circle in panel F denotes the mean of under-ice surface water $a_{\mathrm{CDOM}}(325)$ values at stations F3 and F8. Error bars are one standard deviation.

resembled that of the under-ice surface water, suggesting that the shoulder could at least partly result from the inclusion of seawater CDOM during ice formation. The absorption spectra for the high [chl- $a$ ] phases also displayed the short-UV shoulder but some of them carried an additional broad elevation over 300-350 nm (Fig. 7B), the latter being characteristic of MAAs (Carreto et al., 2005). To assess the contribution of MAAs to $a_{\mathrm{CDOM}}$, an approach similar to that for correcting metal contamination of CDOM absorption (see Section 2.1) was employed to estimate the MAAs-free $a_{\mathrm{CDOM}}$ (Fig. 7B). Subtraction of the MAAs-free $a_{\mathrm{CDOM}}$ from the total (i.e. measured) $a_{\mathrm{CDOM}}$ gives the MAA absorption coefficient, $a_{\text {MAAs }}$. The MAA absorption spectra from different samples all peaked in a narrow band of 323-327 nm (Fig. 7C). The $a_{\text {MAAs }}$ at $325 \mathrm{~nm}$ reached $5.66 \mathrm{~m}^{-1}$ at station D43 (April
26), $4.14 \mathrm{~m}^{-1}$ at station F1 (May 8), $3.25 \mathrm{~m}^{-1}$ at station F1 (May 9), and $5.91 \mathrm{~m}^{-1}$ at station F2 (May 13), contributing 48\%, 31\%, 26\%, and $31 \%$ of the respective total $a_{\mathrm{CDOM}}(325)$.

The CFL sample collected for the photobleaching study presented a pronounced MAA absorption elevation with the wavelength of maximum absorbance $\left(\lambda_{\max }\right)$ at $\sim 325 \mathrm{~nm}$ (Fig. 8A). Exposure of this sample to spectrally amended radiation had little effect on the MAA shoulder at $\lambda_{50 \% \mathrm{~T}} \geq 435 \mathrm{~nm}$ but progressively diminished it with decreasing $\lambda_{50 \% \mathrm{~T}}$ at $\lambda_{50 \% \mathrm{~T}} \leq 395 \mathrm{~nm}$ until it essentially disappeared at $\lambda_{50 \% \mathrm{~T}}=320 \mathrm{~nm}$ (Fig. 8A). Further decreasing $\lambda_{50 \% \mathrm{~T}}$ led to little extra photobleaching. The CASES sample behaved similarly, though its MAA shoulder shifted to shorter wavelengths $\left(\lambda_{\max }: \sim 315 \mathrm{~nm}\right.$, Fig. 8B). These MAAs were thus readily photobleachable by the UV-B (280-320 nm), moderately susceptible to the UV-A (320-400 nm), and resistant to the visible (>400 nm). Apparently, the irradiation durations adopted, $30 \mathrm{~min}$ for CFL and 15 min for CASES, were too long to resolve the spectral dependence of the MAAs photobleaching within the UV-B but short enough to prevent bleaching the residual CDOM devoid of the MAAs.

The absorbed photon-based efficiency, i.e. apparent quantum yield, of MAAs photobleaching ( $A_{Q Y}$ ble, was assessed according to the protocol of Xie et al. (1998) used for deriving the spectral efficiency of carbon disulfide photoproduction in seawater. Briefly, seven quasimonochromatic bands were obtained by subtracting the radiation spectrum under the $(N-1)$ th cutoff filter from the one under the $N$ th cutoff filter, where $N$ decreases at intervals of 1 from 8 (corresponding to the WG280 filter) to 1 (corresponding to the GG495 filter). The center wavelength for each band was identified as where the peak irradiance \left.${\text { occurred. } A Q Y_{\text {ble }}\left(\mathrm{m}^{-1} \text { einstein }\right.}^{-1}\right)$ for each band was estimated as:

$A Q Y_{\text {ble }}=\frac{\int_{\lambda_{1}}^{\lambda_{2}}\left(a_{C D O M}(\lambda)-\left(a_{C D O M}(\lambda)_{N-1}\right) d \lambda\right.}{\int_{280}^{600} Q_{\lambda, N} d \lambda-\int_{280}^{600} Q_{\lambda, N-1} d \lambda .}$

Here $N$ and $N-1$ stand for the $N$ th and $(N-1)$ th cutoff filters, respectively; $\lambda_{1}$ and $\lambda_{2}$ bracket the spectral range of the MAA shoulder (305-380 nm for CFL and 275-365 nm for CASES, Fig. 8A, B); $a_{\text {СDом }}(\lambda)$ is the after-irradiation absorption coefficient; $Q_{\lambda}$ denotes the amount of photons absorbed by CDOM in an irradiation cell.

The obtained $\mathrm{AQY}_{\text {ble }}$ peaked at $369 \pm 22 \mathrm{~nm}$ for the CFL sample and

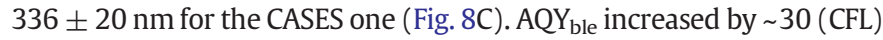
and $\sim 60$ times (CASES) from the visible to the peak wavelengths. Note that the decreasing $\mathrm{AQY}_{\text {ble }}$ toward the UV-B was due to an increasing recalcitrance of the residual CDOM after the MAA peak was largely bleached by the UV-A. These AQY ble values are 6 to 9 orders of magnitude higher than those for MAAs-absent CDOM in the Mackenzie River and on the Mackenzie Shelf (Osburn et al., 2009).

\section{Discussion}

\subsection{Sources and sinks of CDOM in sea ice}

Results from this study (Figs. 3 and 4) demonstrate that the CDOM accumulation in bottom sea ice during the high chl-a phases is clearly associated with ice algal growth, which is consistent with previous reports showing that extracellular release of DOC constitutes a major portion ( $40 \%)$ of primary production in sea ice (Gosselin et al., 1997; Smith et al., 1997). The disconnection between $a_{\mathrm{CDOMi}}(325)$ and [chl-a] during the early bloom stage, however, suggests that ice algae do not produce CDOM until some other drivers are fully developed and involved, such as lysis and grazing (Thomas et al., 1995). This supposition is supported by laboratory incubations of Arctic sea ice algal cultures revealing that CDOM does not significantly build up until the bacterial community was well established ( $\mathrm{G}$. Li et al., unpublished data). Likewise, a field survey has also seen a decoupling of CDOM 
Table 1

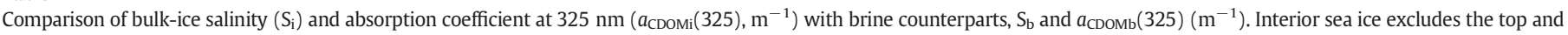

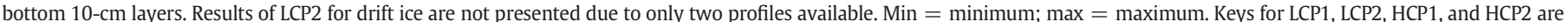
the same as those in Fig. 3.

\begin{tabular}{|c|c|c|c|c|c|c|c|c|c|}
\hline & & \multicolumn{4}{|l|}{ LCP1 } & \multicolumn{4}{|c|}{ HCP1 } \\
\hline & & $\mathrm{S}_{\mathrm{i}}$ & $a_{\text {CDOMi }}(325)$ & $\mathrm{S}_{\mathrm{b}}$ & $a_{\mathrm{CDOMb}}(325)$ & $\mathrm{S}_{\mathrm{i}}$ & $a_{\text {CDOMi }}(325)$ & $\mathrm{S}_{\mathrm{b}}$ & $a_{\text {СDOMb }}(325)$ \\
\hline \multirow[t]{4}{*}{ Top $10 \mathrm{~cm}$} & Min & 6.6 & 0.14 & 133.4 & 3.74 & 6.8 & 0.18 & 102.0 & 2.64 \\
\hline & Max & 9.5 & 0.66 & 318.1 & 23.49 & 9.7 & 0.89 & 178.5 & 11.51 \\
\hline & Mean & 8.5 & 0.29 & 243.5 & 8.67 & 7.8 & 0.32 & 144.5 & 5.44 \\
\hline & S.d. & 1.1 & 0.19 & 69.5 & 7.44 & 1.2 & 0.28 & 33.2 & 3.25 \\
\hline \multirow[t]{4}{*}{ Interior } & Min & 2.7 & 0.11 & 40.7 & 1.62 & 3.5 & 0.14 & 39.9 & 1.96 \\
\hline & Max & 8.4 & 0.69 & 305.0 & 34.79 & 8.2 & 1.04 & 168.3 & 14.64 \\
\hline & Mean & 4.8 & 0.21 & 163.9 & 7.50 & 4.9 & 0.34 & 94.4 & 5.84 \\
\hline & S.d. & 1.1 & 0.12 & 76.4 & 6.27 & 1.1 & 0.21 & 38.2 & 2.75 \\
\hline \multirow[t]{4}{*}{ Bottom $10 \mathrm{~cm}$} & Min & 4.1 & 0.21 & 33.9 & 1.66 & 4.0 & 0.30 & 37.4 & 2.82 \\
\hline & Max & 10.7 & 2.03 & 58.3 & 6.43 & 6.0 & 12.38 & 46.7 & 99.61 \\
\hline & Mean & 6.1 & 0.60 & 41.1 & 3.27 & 5.4 & 6.56 & 41.3 & 47.00 \\
\hline & S.d. & 2.4 & 0.71 & 9.7 & 1.90 & 0.8 & 5.57 & 4.0 & 40.45 \\
\hline
\end{tabular}

Landfast ice

\begin{tabular}{|c|c|c|c|c|c|c|c|c|c|}
\hline & & \multicolumn{4}{|c|}{ HCP2 } & \multicolumn{4}{|c|}{ LCP2 } \\
\hline & & $\mathrm{S}_{\mathrm{i}}$ & $a_{\mathrm{CDOMi}}(325)$ & $S_{b}$ & $a_{\mathrm{CDOMb}}(325)$ & $\mathrm{S}_{\mathrm{i}}$ & $a_{\mathrm{CDOMi}}(325)$ & $\mathrm{S}_{\mathrm{b}}$ & $a_{\mathrm{CDOMb}}(325)$ \\
\hline \multirow[t]{4}{*}{ Top $10 \mathrm{~cm}$} & Min & 3.3 & 0.25 & 33.1 & 3.34 & 0.3 & 0.18 & 1.8 & 1.74 \\
\hline & Max & 6.7 & 0.65 & 90.0 & 6.50 & 6.1 & 1.05 & 68.8 & 6.44 \\
\hline & Mean & 4.8 & 0.44 & 57.4 & 4.91 & 2.3 & 0.47 & 26.1 & 4.03 \\
\hline & S.d. & 1.7 & 0.20 & 29.3 & 1.58 & 2.9 & 0.39 & 32.0 & 2.13 \\
\hline \multirow[t]{4}{*}{ Interior } & Min & 3.4 & 0.20 & 31.3 & 2.63 & 0.7 & 0.21 & 3.7 & 1.04 \\
\hline & Max & 6.4 & 1.02 & 81.5 & 8.49 & 7.5 & 1.10 & 69.6 & 18.11 \\
\hline & Mean & 4.6 & 0.45 & 50.5 & 4.63 & 3.4 & 0.48 & 32.0 & 4.27 \\
\hline & S.d. & 0.8 & 0.22 & 14.3 & 1.65 & 1.1 & 0.21 & 18.5 & 2.97 \\
\hline \multirow[t]{4}{*}{ Bottom $10 \mathrm{~cm}$} & Min & 7.5 & 12.58 & 30.5 & 58.33 & 1.0 & 0.45 & 11.0 & 4.10 \\
\hline & Max & 8.0 & 19.10 & 34.8 & 72.73 & 4.0 & 1.51 & 39.1 & 16.82 \\
\hline & Mean & 7.8 & 15.84 & 32.6 & 65.53 & 2.6 & 0.71 & 28.4 & 9.04 \\
\hline & S.d. & 0.4 & 4.61 & 3.1 & 10.18 & 1.4 & 0.45 & 11.2 & 6.21 \\
\hline
\end{tabular}

from [chl-a] during the early stage of a Ross Sea Phaeocystis Antarctica bloom (Kieber et al., 2009).

In contrast to the lowermost layer, the above-bottom section of sea ice show no meaningful relationships between $a_{\mathrm{CDOMi}}(325)$ and [chla] (data not shown), suggesting that abiotic processes may be important in controlling CDOM there. During sea ice formation, DOM in ambient seawater is partially enclosed in sea ice roughly in proportion to salts (Thomas and Papadimitriou, 2003). In the absence of other contributors, CDOM abundance in sea ice should linearly increase with salinity. However, in coastal and shelf regions receiving major freshwater runoffs, like the southeastern Beaufort Sea, riverine and resuspended organic matter can be trapped into sea ice (Rachold et al., 2004), thereby compromising the otherwise linear CDOM versus salinity correspondence. Yet, terrestrial DOM is generally enriched with color, giving higher specific abundance values (Zepp, 2003) as indicated by the DOC-normalized absorption coefficient at $254 \mathrm{~nm}$, SUVA(254) (Weishaar et al., 2003). We then divided the $a_{\mathrm{CDOMi}}(325)$ data into two groups, one with SUVA $(254)<0.0255 \mathrm{~m}^{2} \cdot \mathrm{mmolC}^{-1}$ and the other with $\operatorname{SUVA}(254)>0.0255 \mathrm{~m}^{2} \cdot \mathrm{mmolC}^{-1}$, excluding the bottom $10-30-\mathrm{cm}$ layer within which the presence of ice algae is evident. Note that the choice of SUVA(254) of $0.0255 \mathrm{~m}^{2} \cdot \mathrm{mmolC}^{-1}$ is not intended to give a clear cut between terrestrial and marine material but, instead, is purported to minimize the terrestrial influence in the first data group. The $a_{\mathrm{CDOMi}}(325)$ is linearly and positively correlated with salinity at $\operatorname{SUVA}(254)<0.0255 \mathrm{~m}^{2} \cdot \mathrm{mmolC}^{-1}$ (Fig. 9A) while a much more scattered relationship transpires at $\operatorname{SUVA}(254)>0.0255$ $\mathrm{m}^{2} \cdot \mathrm{mmolC}^{-1}$ (Fig. 9B). The linear relationship, however, holds only for drift ice before ice melt. The lack of correlation between $a_{\mathrm{CDOMi}}(325)$ and salinity for landfast ice could be due to the presence of other CDOM endmembers, such as organic matter from aeolian deposition (Macdonald et al., 2004) and biological organic matter production within the interior ice. The latter is more likely during the advanced stages of the ice melt when the formation of superimposed ice promotes the development of a distinct interior ice biological community (Mundy et al., 2011).

In regard to loss of CDOM in sea ice, the rapid drawdown of CDOM in mid-May is most likely due to brine convection which does not occur substantially until surface ice begins melting (Song et al., 2011). Brine drainage leads to loss of not only sea-ice CDOM but also its primary source: the sympagic organisms. CDOM in sea ice may also undergo biodegradation but little is documented in the literature. A concurrent microbiological study by Nguyen and Maranger (2011) obtained a potential bacterial respiration rate as high as $14.4 \mu g \mathrm{C} \mathrm{L}^{-1} \mathrm{~d}^{-1}$ (1.20 $\left.\mu \mathrm{molC} \mathrm{L}^{-1} \mathrm{~d}^{-1}\right)$ for the bottom 4.5-cm ice from late March to early July. If bacteria in the lowermost $10-\mathrm{cm}$ ice mineralizes DOC at similar rates, the amount of DOC respired over our sampling period $\left(113 \mathrm{~d}, 136 \mu \mathrm{molC} \mathrm{L}^{-1}\right)$ is equivalent to $55 \%$ of the net production of DOC in drift ice and 13\% in landfast ice based on the sea-ice DOC data reported by Song et al. (2011). As the bacterial respiration shows no trend over time (Nguyen and Maranger, 2011), DOC production rates comparable to the bacterial respiration rates are required to maintain the relatively stable DOC concentrations during the early and late spring seasons (Song et al., 2011). Although CDOM may not necessarily be respired at rates similar to those of DOC, the results of Nguyen and Maranger (2011) do suggest that microbial uptake is a potentially significant sink of CDOM in sea ice. Other potential loss processes include diffusion into the underlying seawater and photooxidation (Belzile et al., 2000; Xie and Gosselin, 2005); the lack of relevant measurements, however, does not permit to discuss these processes in any quantitative sense.

\subsection{Net production of CDOM in bottom sea ice}

Individual profiles of $a_{\mathrm{CDOMi}}$ (325) indicate that the accumulation of ice algae-derived CDOM during the high [chl-a] phases is confined to the lowermost $30-\mathrm{cm}$ layer, predominantly within the bottom $10 \mathrm{~cm}$. 
A)

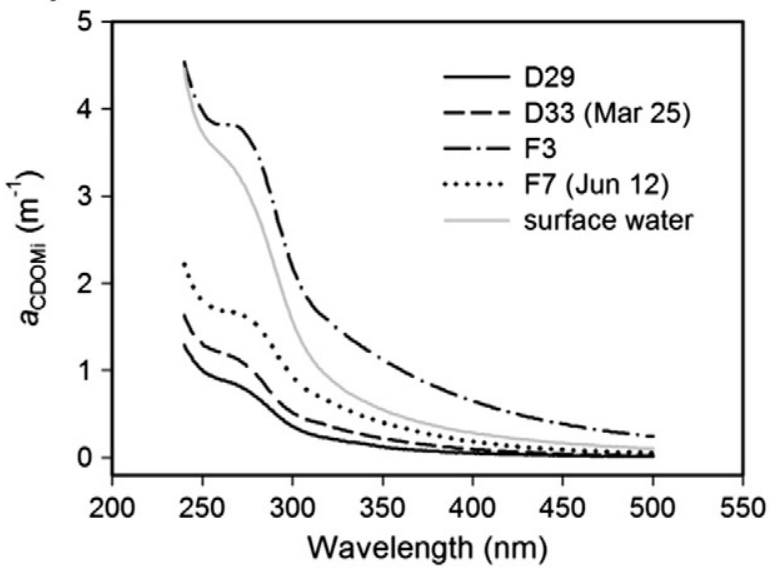

B)

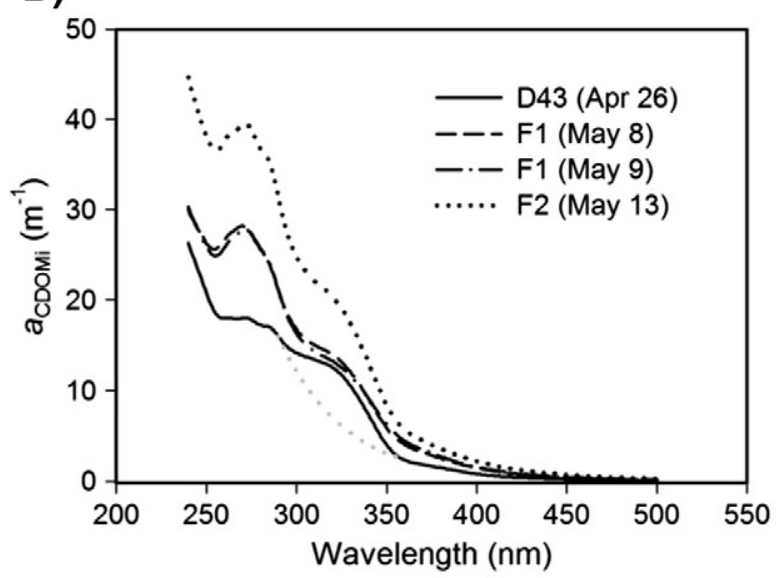

C)

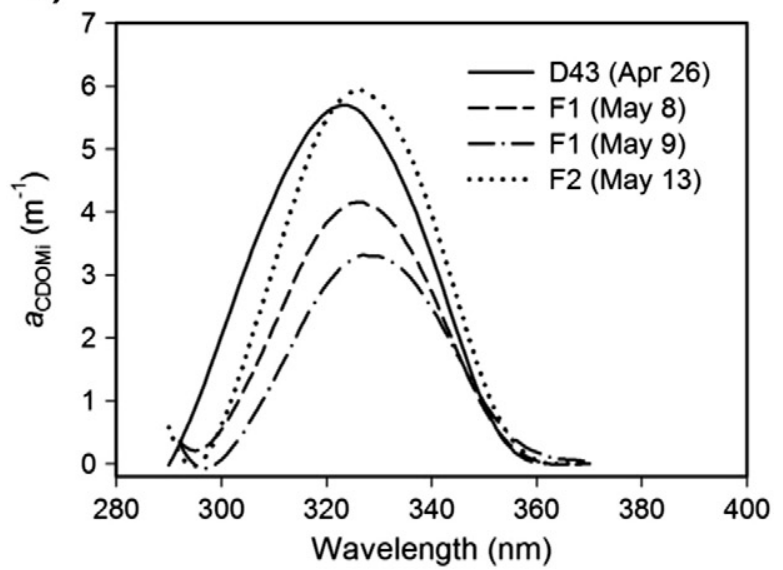

Fig. 7. Typical CDOM absorption spectra in the bottommost $10-\mathrm{cm}$ ice layer during the low [chl- $a$ ] phases (A) and high [chl- $a$ ] phases (B). The under-ice surface water absorption spectrum at station D43 is included in panel A for comparison. The dotted gray line in panel B represents $a_{\mathrm{CDOMi}}$ free of MAAs for station D43 over the MAA spectral band estimated from an exponential fit of measured $a_{\mathrm{CDOMi}}$ to wavelength over 285-292 nm and 360-370 nm combined. Similar treatments were performed for the other three samples but their fitted lines are omitted for clarity. MAA absorption spectra (C) were derived from subtraction of the MAAs-free $a_{\mathrm{CDOMi}}$ from the measured $a_{\mathrm{CDOMi}}$.

We estimated the net production of CDOM of algal origin as the difference in the CDOM inventory in the lowermost 30-cm layer between the high [chl- $a$ ] phases and the first four sampling days (i.e. 17-28 March, Fig. 3), taking the latter as the background CDOM inventory free of the ice algal component. The $a_{\mathrm{CDOMi}}(325)$-based CDOM
A)

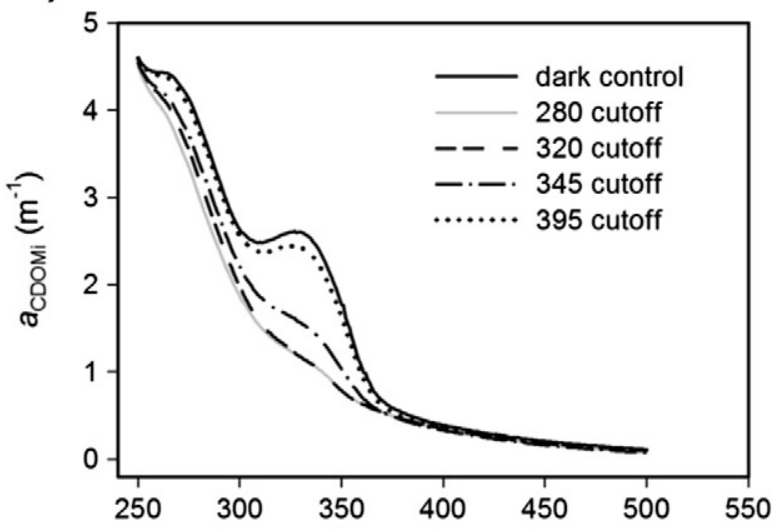

B)

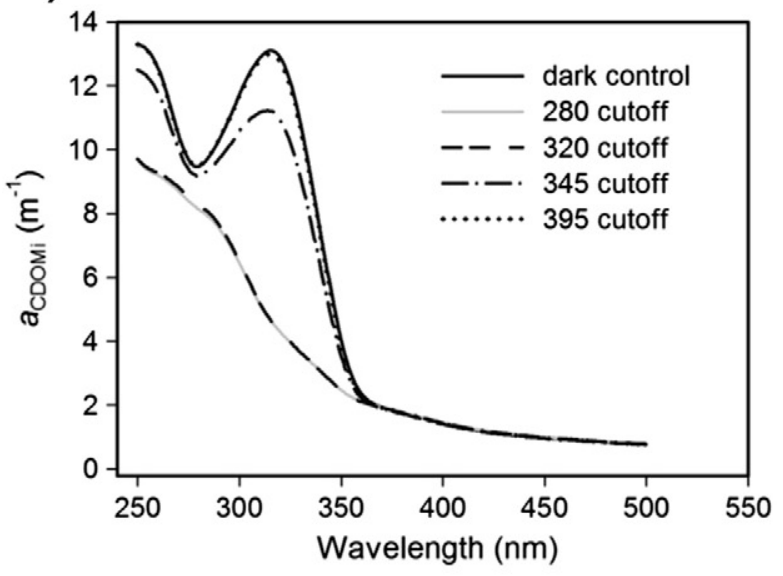

C)

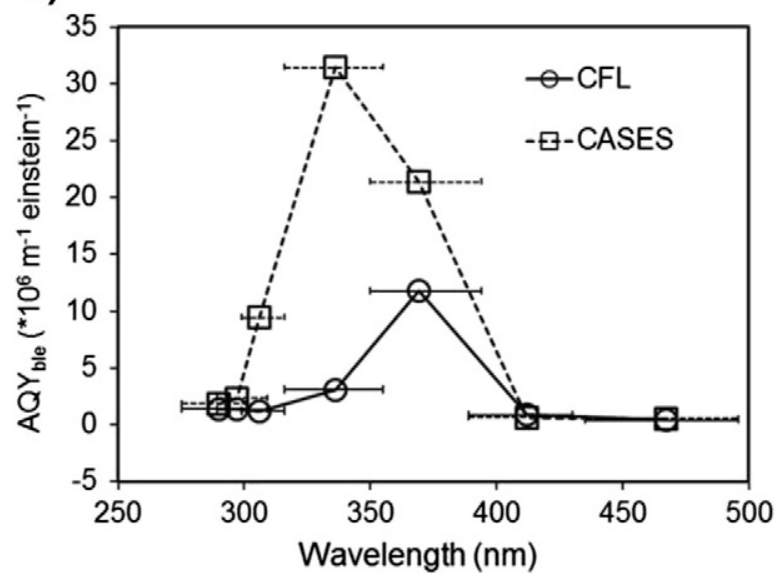

Fig. 8. Photobleaching of absorption peaks associated with MAAs (A: CFL and B: CASES) and apparent quantum yield of photobleaching (C). Numbers in symbol legends of panels A and B signify the nominal 50\%-transmittance cutoff wavelengths. Cutoff wavelengths at 295, 305, 435, and $495 \mathrm{~nm}$ are not shown for clarity. Panel A denotes the CFL sample (station F2) and panel B refers to the CASES sample collected in the Franklin Bay in May 2004. Horizontal error bars in panel $C$ represent wavelength band widths at half-peak irradiances.

inventories (mean \pm s.d.) are: $0.045 \pm 0.005$ for the background, $0.61 \pm 0.15$ for HCP1 (drift ice), and $0.76 \pm 0.21$ for HCP2 (landfast ice). Note that the inventory, defined as the depth-integrated absorption coefficient of $C D O M$, is dimensionless. These inventories arrive at net CDOM productions of 0.56 for drift ice and 0.72 for landfast ice; they approximate the net contributions to the under-ice water CDOM pool, given that $a_{\mathrm{CDOMi}}(325)$ during the melting season is comparable 

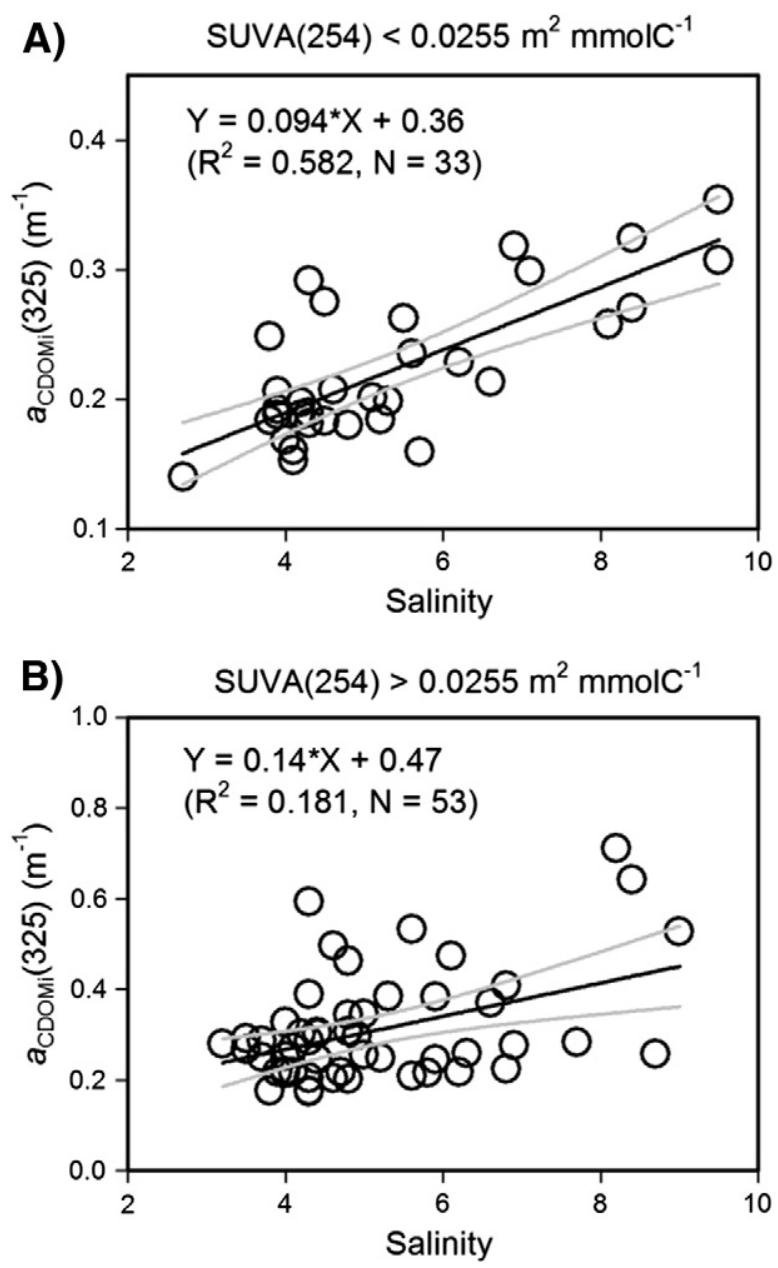

Fig. 9. Scatter plots of $a_{\mathrm{CDOMi}}$ (325) versus salinity at SUVA(254) $<0.0255 \mathrm{~m}^{2} \cdot \mathrm{mmolC}^{-1}$ (A) and SUVA(254) $>0.0255 \mathrm{~m}^{2} \cdot \mathrm{mmolC}^{-1}$ (B) for drift ice over LCP1 and HCP1 as defined in Fig. 3. Gray lines denote $95 \%$ confidence intervals. Data for the bottommost 10 -cm layer are excluded.

to $a_{\mathrm{CDOMw}}(325)$ in the underlying seawater (Fig. 3 and Fig. $6 \mathrm{~F}$ ). The CDOM inventory in the upper mixed layer of the under-ice water column ( 19 m deep, Song et al., 2011) is estimated to be 13.0, using the mean $a_{\mathrm{CDOMw}}(325)\left(0.63 \pm 0.2 \mathrm{~m}^{-1}\right)$ (Fig. 3 ) and assuming homogeneity of CDOM within the upper mixed layer. The net contributions of CDOM from sea ice thus only represent $4-6 \%$ of the CDOM standing stock in the upper mixed layer. Sea-ice CDOM therefore experiences massive dilution upon being released into the underlying water, which is consistent with the little temporal variation in $a_{\mathrm{CDOMw}}(325)$ (Fig. 3) and the lack of noticeable signatures of MAAs in the absorption spectrum of the under-ice water CDOM (Fig. 7A).

\subsection{Ecological implications of CDOM in sea ice}

Despite being a minor source to the under-ice water CDOM pool, sea-ice CDOM is set to profoundly impact the ecology of sympagic organisms. The highly enriched CDOM in brine (Table 1) suggests that an overall vertical length of several centimeters of brine channels or pockets can prevent the majority of UV radiation reaching the bottom, thereby greatly mitigating the UV harmful effect on ice algae. Because of the low UV radiation entering the bottom ice, the photochemical turnover of the MAAs is expected to be relatively long, which provides further UV photoprotection. Xie and Gosselin (2005) modeled the UV photon fluxes reaching the lowermost 10 -cm layer of a $190-\mathrm{cm}$ thick, snow-covered ice column in the Franklin Bay $\left(70^{\circ} \mathrm{N}, 133^{\circ} \mathrm{W}\right)$, where our MAA samples were collected. The modeled mid-May noontime fluxes under cloudless conditions are $1.11 \times 10^{-9}$ einsteins $\mathrm{m}^{-2} \mathrm{~s}^{-1}$ in the UV-B and $1.69 \times 10^{-7}$ einsteins $\mathrm{m}^{-2} \mathrm{~s}^{-1}$ in the UV-A, representing $0.007 \%$ and $0.2 \%$ of the UV-B $\left(1.52 \times 10^{-5}\right.$ einsteins $\left.\mathrm{m}^{-2} \mathrm{~s}^{-1}\right)$ and UV-A $\left(9.14 \times 10^{-5}\right.$ einsteins $\left.\mathrm{m}^{-2} \mathrm{~s}^{-1}\right)$ fluxes used for the laboratory irradiation study. The field UV-B flux is negligible compared to that employed for the irradiation experiment. Scaling the on-site UV-A flux to the laboratory one, alongside the lab-based photochemical MAA turnover times of 15-30 min (see Section 3.5), arrives at field turnover times of 5.6-11.2 $\mathrm{d}$. These turnover time values are prolonged to 32-64 d considering that cloudiness reduces surface irradiance by $\sim 30 \%$ in the Arctic (Xie et al., 2009) and that 1-d insolation is equivalent to $~ 6-\mathrm{h}$ noontime insolation. Note that these estimates are likely lower limits, since measured transmittances in that area under similar snow and ice conditions (Ehn et al., 2008) are an order of magnitude lower than those employed in our model, which are obtained from the studies of Perovich (1995, 2002). Therefore, even a fairly low MAA production is sufficient to maintain significant levels of these compounds in bottom ice. However, snow and ice melting and formation of melt ponds in late spring dramatically diminish the surface albedo (Perovich, 2002; Ehn et al., 2008), allowing much greater UV radiation penetration (Belzile et al., 2000) and thereby ushering a rapid turnover of the MAAs. It is expected that the fast decay renders the MAAs to provide little UV photoprotection to ice algae at the melting stage which synchronizes the end of the algal bloom (Fig. 3). The UV susceptibility of MAAs elucidated here also offers a plausible explanation for the observation of Ryan et al. (2002) revealing a nearly complete loss of MAAs in a bottom ice-algal community of Antarctic sea ice under an artificial enhancement of the UV-B radiation.

Previous studies have demonstrated that photodegradation of MAAs is a photosensitized process involving reactive oxygen species (ROS) (Bernillon et al., 1990; Whitehead and Hedges, 2005). CDOM is a wellknown photosensitizer in natural waters which can generate a suite of ROS (Zafiriou et al., 1984; Blough and Zepp, 1995). It is highly probable that the fast photodecomposition of MAAs observed in the present study results from strong photosensitization driven by CDOM which is affluent in bottom ice during the ice algal bloom (Fig. 3). Moreover, excessively high levels of dissolved iron often residing in sea ice (Aguilar-Islas et al., 2008; de Jong et al., 2013) accelerate the production of ROS through the photo-Fenton reaction (Zepp et al., 1992), thus further increasing the photosensitizing capacity of CDOM.

Finally, the UV absorption shoulders in the 250-300 nm spectral range (Fig. 7) are similar to those spotted in Antarctic sea ice by Norman et al. (2011). The compounds responsible for these absorption shoulders unlikely serve as UV photoprotectants, since their absorbance bands are beyond the spectra of solar radiation at the earth's surface. However, they are readily photodegradable by solar UV radiation (Fig. 8) and thus participate in organic matter cycling. Further studies are needed to elucidate the chemical identities of the MAAs and shorter-UV absorbing compounds, the mechanisms underlying their high photoreactivity, and their physiological and ecological functions.

\section{Summary and conclusions}

CDOM abundance in the bottom sea ice generally co-varied with [chl-a], remaining low in early spring, reaching maxima during the mid-spring ice algal bloom, and quickly leveling off at the onset of ice melting in late spring. An exception occurred at the early stage of the bloom during which the progression of CDOM lagged behind that of [chl-a]. Maximum CDOM loads in the bottom layer of landfast ice were substantially higher than those in drift ice. CDOM abundances in the surface and interior ice were lower than those in the bottom ice, the difference being particularly striking during the peak bloom of ice algae. Above the bottom layer, CDOM exhibited little vertical gradients and spatiotemporal variations. While the bottom layer was highly enriched with CDOM relative to the under-ice seawater, the upper ice was depleted with or held similar contents of CDOM as compared to the under-ice seawater. 
CDOM in the bottom layer mainly originates from ice algae while inclusion of dissolved materials from seawater during ice formation is likely a major source of CDOM in the upper ice. The production of CDOM by ice algae is only a minor source of CDOM to the underlying water column. Sea-ice CDOM, which is dominantly present in brine where sympagic organisms dwell, is expected to play an important UV-shielding role. The high photoreactivity of MAAs suggests that these compounds can function as effective UV-photoprotectants only under low-UV conditions.

\section{Acknowledgments}

We thank M. Gosselin, C. J. Mundy, B. Philippe, C. Nozais, S. Pineault, C. Lacoste, J. Ehn, R. Memorana, and many others for their help with sea ice coring. We appreciate the cooperation of the chief scientists, captains, and crews of the CFL and CASES cruises. Reviewers' comments improved the manuscript. This study was supported by grants from the Canadian International Polar Year (IPY) federal program office and the Natural Sciences and Engineering Research Council of Canada (NSERC). The CFL and CASES programs were under the overall direction of D. Barber and L. Fortier, respectively. This is a contribution to the research programs of CFL, CASES, ISMER, and Québec-Océan.

\section{References}

Aguilar-Islas, A.M., Rember, R.D., Mordy, C.W.,Wu, J., 2008. Sea ice-derived dissolved iron and its potential influence on the spring algal bloom in the Bering Sea. Geophys. Res. Lett. 35, L24601. http://dx.doi.org/10.1029/2008GL035736.

Antoine, D., André, J.M., Morel, A., 1996. Oceanic primary production: II. Estimation at global scale from satellite (Coastal Zone Color Scanner) chlorophyll. Glob. Biogeochem. Cycles 10, 57-69.

Babin, M.,Stramski, D.,Ferrari, G.M.,Claustre, H.,Bricaud, A.,Obolensky, G.,Hoepffner, N., 2003. Variations in the light absorption coefficients of phytoplankton, nonalgal particles, and dissolved organic matter in coastal waters around Europe. J. Geophys. Res. 108, 3211. http://dx.doi.org/10.1029/2001JC000882.

Barber, D.G., Asplin, M.D., Gratton, Y.,Lukovich, J.V., Galley, R., Raddatz, R.J.,Leitch, D., 2010. The international polar year (IPY) circumpolar flaw lead (CFL) system study: introduction and physical system. Atmos. Ocean. 48, 225-243.

Barber, D.G., Asplin, M.G., Papakyriakou, T.N., Miller, L., Else, B.G.T., Iacozza, J., Mundy, C.J., Gosslin, M., Asselin, N.C., Ferguson, S., Lukovich, J.V., Stern, G.A., Gaden, A., Pućko, M., Geilfus, N.-X., Wang, F., 2012. Consequences of change and variability in sea ice on marine ecosystem and biogeochemical processes during the 2007-2008 Canadian International Polar Year program. Clim. Chang. 115, 135-159.

Belzile, C.,Johannessen, S.C., Gosselin, M., Demers, S., Miller, W.L., 2000. Ultraviolet attenuation by dissolved and particulate constituents of first-year ice during late spring in an Arctic polynya. Limnol. Oceanogr. 45, 1265-1273.

Bernillon, J., Parussini, E., Letoublon, R., Favre-Bonvin, J., Arpin, N., 1990. Flavin-mediated photolysis of mycosporines. Phytochemistry 29, 81-84.

Blough, N.V.,Zepp, R.G., 1995. Reactive oxygen species in natural waters. In: Foote, C.S. Valentine, J.S., Greenberg, A., Liebman, J.F. (Eds.), Active Oxygen in Chemistry. Chapman \& Hall, New York, pp. 280-333.

Brown, T.A.,Belt, S.T.,Philippe, B.,Mundy, C.J.,Massé, G.,Poulin, M.,Gosselin, M., 2010. Temporal and vertical variations of lipid biomarkers during a bottom ice diatom bloom in the Canadian Beaufort Sea: further evidence for the use of the IP25 biomarker as a proxy for spring Arctic sea ice. Polar Biol. 34, 1857-1868.

Carreto, J.I., Carignan, M.O., Montoya, N.G., 2005. A high-resolution reverse-phase liquid chromatography method for the, analysis of mycosporine-like amino acids (MAAs) in marine organisms. Mar. Biol. 146, 237-252.

De Jong, J., Schoemann, V., Maricq, N., Mattielli, N., Langhorne, P., Haskell, T., Tison, J.-L., 2013. Iron in land-fast sea ice of McMurdo Sound derived from sediment resuspension and wind-blown dust attributes to primary productivity in the Ross Sea. Antarct. Mar. Chem. 157, 24-40.

Ehn, J., Granskog, M.A.,Reinart, A.,Erm, A., 2004. Optical properties of melting landfast sea ice and underlying seawater in Santala Bay, Gulf of Finland. J. Geophys. Res. 109, C09003. http://dx.doi.org/10.1029/2003JC002042.

Ehn, J.K.,Mundy, C.J.,Barber, D.G., 2008. Bio-optical and structural properties inferred from irradiance measurements within the bottommost layers in an Arctic landfast sea ice cover. J. Geophys. Res. 113, C03S03. http://dx.doi.org/10.1029/2007JC004194.

Eicken, H., 2003. From the microscopic, to the macroscopic, to the regional scale: growth, microstructure and properties of sea ice. In: Thomas, D.N., Dieckmann, G.S. (Eds.), Sea Ice: An Introduction to its Physics, Chemistry, Biology, and Geology. Blackwell Science, Oxford, UK, pp. 22-81.

Fortier, L., Cochran, J.K., 2008. Introduction to special section on Annual Cycles on the Arctic Ocean Shelf. J. Geophys. Res. 113, C03S00. http://dx.doi.org/10.1029/ 2007JC004457.

Gosselin, M., Levasseur, M., Wheeler, P.A., Horner, R.A., Booth, B.C., 1997. New measurements of phytoplankton and ice algal production in the Arctic Ocean. Deep-Sea Res. II $44,1623-1644$.
Granskog, M.A., Kaartokallio, H., Thomas, D.N., Kuosa, H., 2005. Influence of freshwater inflow on the inorganic nutrient and dissolved organic matter within coastal sea ice and the underlying waters in the Gulf of Finland (Baltic Sea). Estuar. Coast. Shelf Sci. $65,109-122$.

Granskog, M.,Kaartokallio, H.,Kuosa, H.,Thomas, D.N.,Vainio, J., 2006. Sea ice in the Baltic: a review. Estuar. Coast. Shelf Sci. 70, 145-160.

Granskog, M.A.,Stedmon, C.A.,Dodd, P.A.,Amon, R.M.W.,Pavlov, A.K.,deSteur, L.,Hansen, E., 2012. Characteristics of colored dissolved organic matter (CDOM) in the Arctic outflow in the Fram Strait: assessing the changes and fate of terrigenous CDOM in the Arctic Ocean. J. Geophys. Res. 117, C12021. http://dx.doi.org/10.1029/2012JC008075.

Guéguen, C., Guo, L.,Yamamoto-Kawai, M.,Tanaka, N., 2007. Colored dissolved organic matter dynamics across the shelf-basin interface in the western Arctic Ocean. J. Geophys. Res. 112, C05038. http://dx.doi.org/10.1029/2006JC003584.

Hill, V.J., 2008. Impacts of chromophoric dissolved organic material on surface ocean heating in the Chukchi Sea. J. Geophys. Res. 113, C07024. http://dx.doi.org/10.1029/ 2007JC004119.

Kieber, D.J., Toole, D.A., Kiene, R.P., 2009. Chromophoric dissolved organic matter cycling during a Ross Sea Phaeocystis Antarctica bloom. In: Krupnik, I., Lang, M.A., Miller, S. E. (Eds.), Smithsonian at the Poles: Contributions to International Polar Year Science - A Smithsonian Contribution to Knowledge. Smithsonian Institute Scholarly Press, Washington, D.C., pp. 319-333.

Kirk, J.T.O., 1980. Spectral absorption properties of natural waters: Contribution of the soluble and particulate fractions to light absorption in some inland waters of Southeastern Australia. Aust. J. Mar. Freshwat. Res. 31, 287-296.

Lizotte, M.P., 2003. The microbiology of sea ice. In: Thomas, D.N., Dieckmann, G.S. (Eds.), Sea Ice: An Introduction to its Physics, Chemistry, Biology, and Geology. Blackwell Science, Oxford, UK, pp. 184-210.

Macdonald, R.W., Naidu, A.S., Yunker, M.B., Gobeil, C., 2004. The Beaufort Sea: distribution, sources, fluxes, and burial rates of organic carbon. In: Stein, R., Macdonald, R.W. (Eds.), The Organic Carbon Cycle in the Arctic Ocean. Springer, Berlin, pp. 177-192.

Matsuoka, A., Bricaud, A., Benner, R., Para, J., Sempéré, R., Prieur, L., Bélanger, S., Babin, M., Boss, E., 2012. Tracing the transport of colored dissolved organic matter in water masses of the Southern Beaufort Sea: relationship with hydrographic characteristics. Biogeosciences 9, 925-940.

Mundy, C.J., Gosselin, M., Ehn, J., Gratton, Y.,Rossnagel, A., Barber, D.G., Martin, J., Tremblay, J.-É., Palmer, M., Arrigo, K.R., Darnis, G., Fortier, L., Else, B., Papakyriakou, T., 2009. Contribution of under-ice primary production to an ice-edge upwelling phytoplankton bloom in the Canadian Beaufort Sea. Geophys. Res. Lett. 36, L17601. http://dx.doi. org/10.1029/2009GL038837.

Mundy, C.J., Gosselin, M., Ehn, J.K., Belzile, C., Poulin, M., Alou, E., Roy, S., Hop, H., Lessard, S. Papakyriakou, T.N., Barber, D.G.,Stewart, J., 2011. Characteristics of two distinct highlight acclimated algal communities during advanced stages of sea ice melt. Polar Biol. 34, 1869-1886.

Nelson, N.B.,Siegel, D.A.,Carlson, C.A.,Swan, C.M., 2010. Tracing global biogeochemical cycles and meridional overturning circulation using chromophoric dissolved organic matter. Geophys. Res. Lett. 37, L03610. http://dx.doi.org/10. 1029/2009GL042325.

Nguyen, D., Maranger, R., 2011. Respiration and bacterial carbon dynamics in Arctic sea ice. Polar Biol. 34, 1843-1855.

Norman, L., Thomas, D.N., Stedmon, C.A., Granskog, M.A., Papadimitriou, S., Krapp, R.H., Meiners, K.M., Lannuzel, D., van der Merwe, P.,Dieckmann, G.S., 2011. The characteristics of dissolved organic matter (DOM) and chromophoric dissolved organic matter (CDOM) in Antarctic sea ice. Deep-Sea Res. II 58, 1075-1091.

Opsahl, S., Benner, R., Amon, R.M.W., 1999. Major flux of terrigenous dissolved organic matter through the Arctic Ocean. Limnol. Oceanogr. 44, 2017-2023.

Osburn, C.L., Retamal, L.,Vincent, W.F., 2009. Photoreactivity of chromophoric dissolved organic matter transported by the Mackenzie River to the Beaufort Sea. Mar. Chem. $115,10-20$.

Pegau, W.S., 2002. Inherent optical properties of the central Arctic surface waters. J Geophys. Res. 107, 8035. http://dx.doi.org/10.1029/2000JC000382.

Perovich, D.K., 1995. Observation of ultraviolet light reflection and transmission by firstyear sea ice. Geophys. Res. Lett. 22, 1349-1352.

Perovich, D.K., 2002. UV and the optical properties of sea ice and snow. In: Hessen, D.O (Ed.), UV Radiation and Arctic Ecosystem. Springer, Berlin, pp. 73-89.

Peterson, B.J., Holmes, R.M., McClelland, J.W.,Vorosmarty, C.J., Lammers, R.B., Shiklomanov A.I., Rahmstorf, S., 2002. Increasing river discharge to the Arctic Ocean. Science 298, 2171-2173.

Rachold, V., Eicken, H., Gordeev, V.V., Grigoriev, M.N., Hubberten, H.-W., Lisitzin, A.P., Shevchenko, V.P., Schirmeister, L., 2004. Modern terrigenous organic carbon input to the Arctic Ocean. In: Stein, R., Macdonald, R.W. (Eds.), The Organic Carbon Cycle in the Arctic Ocean. Springer, Berlin, pp. 33-54.

Randall, K., Scarratt, M., Levasseur, M., Michaud, S., Xie, H., Gosselin, M., 2012. First measurements of nitrous oxide in Arctic sea ice. J. Geophys. Res. 117, C00G15. http://dx. doi.org/10.1029/2011JC007340.

Ryan, K.G., McMinn, A., Mitchell, K.A., Trenerry, L., 2002. Mycosporine-like amino acids in antarctic sea ice algae, and their response to UVB radiation. Z. Naturforsch. 57c $471-477$.

Scully, N.M.,Miller, W.L., 2000. Spatial and temporal dynamics of colored dissolved organic matter in the North Water polynya. Geophys. Res. Lett. 27, 1009-1011.

Smith, R.E.H., Gosselin, M., Kudoh, S., Robineau, B., Taguchi, S., 1997. DOC and its relationship to algae in bottom ice communities. J. Mar. Syst. 11, 71-80.

Song, G.,Xie, H., Aubry, C.,Zhang, Y., Gosselin, M.,Mundy, C.J.,Philippe, B.,Papakyriakou, T.N., 2011. Spatiotemporal variations of dissolved organic carbon and carbon monoxide in first-year sea ice in the western Canadian Arctic. J. Geophys. Res. 116, C00G05. http://dx.doi.org/10.1029/2010JC006867. 
Stedmon, C.A.,Amon, R.M.W.,Rinehart, A.J.,Walker, S.A., 2011a. The supply and characteristics of colored dissolved organic matter (CDOM) in the Arctic Ocean: Pan Arctic trends and differences. Mar. Chem. 124, 108-118.

Stedmon, C.A., Thomas, D.N., Papadimitriou, S., Granskog, M.A., Dieckmann, G.S., 2011b. Using fluorescence to characterize dissolved organic matter in Antarctic sea ice brines. J. Geophys. Res. 116, G03027. http://dx.doi.org/10.1029/2011JG001716.

Thomas, D.N., Papadimitriou, S., 2003. Biogeochemistry of sea ice. In: Thomas, D.N., Dieckmann, G.S. (Eds.), Sea Ice: An Introduction to its Physics, Chemistry, Biology, and Geology. Blackwell Science, Oxford, UK, pp. 267-302.

Thomas, D.N.,Lara, R.J., Eicken, H., Kattner, G.,Skoog, A., 1995. Dissolved organic matter in Arctic multi-year sea ice during winter: major components and relationship to ice characteristics. Polar Biol. 15, 477-483.

Thomas, D.N.,Lara, R.J.,Haas, C.,Schnack-Schiel, S.B.,Dieckmann, G.S., Kattner, G.,Nöthig, E.M., Mizdalski, E., 1998. Biological soup within decaying summer sea ice in the Amundsen Sea, Antarctica. In: Lizotte, M.P., Arrigo, K.R. (Eds.), Antarctic Sea Ice Biological Processes, Interactions, and Variability, 73. American Geophysical Union. Antarctic Research Series, pp. 161-171.

Thomas, D.N., Kattner, G., Engbrodt, R., Giannelli, V., Kennedy, H.,Haas, C., Dieckmann, G.S. 2001. Dissolved organic matter in Antarctic sea ice. Ann. Glaciol. 33, 297-303.

Uusikivi, J., Vähätalo, A., Granskog, M.A., Sommaruga, R., 2010. Contribution of mycosporine-like amino acids, colored dissolved and particulate matter on sea ice optical properties and ultraviolet attenuation. Limnol. Oceanogr. 55, 703-713.

Weishaar, J.L.,Aiken, G.R., Bergamaschi, B.A., Fram, M.S., Fujii, R., Mopper, K., 2003. Evaluation of specific ultraviolet absorbance as an indicator of the chemical composition and reactivity of dissolved organic carbon. Environ. Sci. Technol. 37, 4702-4708.
Whitehead, K., Hedges, J.I., 2005. Photodegradation and photosensitization of mycosporine-like amino acids. J. Photochem. Photobiol. B Biol. 80, 115-121.

Xie, H., Gosselin, M., 2005. Photoproduction of carbon monoxide in first-year sea ice in Franklin Bay, southeastern Beaufort Sea. Geophys. Res. Lett. 32, L12606. http://dx. doi.org/10.1029/2005GL022803.

Xie, H., Moore, R.M., Miller, W.L., 1998. Photochemical production of carbon disulphide in seawater. J. Geophys. Res. 103, 5635-5644.

Xie, $H_{\text {, }}$ Bélanger, $S$. Demers, S Vincent, W.F, Papakyriakou, T.N., 2009. Photobiogeochemical cycling of carbon monoxide in the southeastern Beaufort Sea in spring and autumn. Limnol. Oceanogr. 54, 234-249.

Xie, H.,Aubry, C., Bélanger, S., Song, G., 2012. The dynamics of absorption coefficients of CDOM and particles in the St. Lawrence estuarine system: biogeochemical and physical implications. Mar. Chem. 128-129, 44-56.

Zafiriou, 2002. Sunburnt organic matter: biogeochemistry of light-altered substrates. Limnol. Oceanogr. Bull. 11, 69-74.

Zafiriou, O.C., Joussot-Dubien, J., Zepp, R.G.,Zika, R.G., 1984. Photochemistry of natural waters. Environ. Sci. Technol. 18, 358A-371A

Zepp, R.G., 2003. Solar UVR and aquatic carbon, nitrogen, sulfur and metals cycles. In: Helbling, E.W., Zagarese, H. (Eds.), UV Effects in Aquatic Organisms and Ecosystems. The Royal Society of Chemistry, Cambridge, UK, pp. 137-184.

Zepp, R.G., Faust, B.C., Hoigne, J., 1992. Hydroxyl radical formation in aqueous reactions ( $\mathrm{pH}$ 3-8) of iron(II) with hydrogen peroxide: the photo-Fenton reaction. Environ. Sci. Technol. 26, 313-319.

Zhang, Y., Xie, H., Chen, G., 2006. Factors affecting carbon monoxide photoproduction in the St. Lawrence estuarine system (Canada). Environ. Sci. Technol. 40, 771-777. 